University of South Florida

DIGITAL COMMONS

Digital Commons @ University of

@ UNIVERSITY OF SOUTH FLORIDA

South Florida

School of Geosciences Faculty and Staff

Publications

School of Geosciences

$12-1989$

\title{
Topographic and Volcanic Asymmetry around the Red Sea: Constraints on Rift Models
}

Timothy H. Dixon

California Institute of Technology, thd@usf.edu

Erik R. Ivins

California Institute of Technology

Brenda J. Franklin

California Institute of Technology

Follow this and additional works at: https://digitalcommons.usf.edu/geo_facpub

Part of the Earth Sciences Commons

\section{Scholar Commons Citation}

Dixon, Timothy H.; Ivins, Erik R.; and Franklin, Brenda J., "Topographic and Volcanic Asymmetry around the Red Sea: Constraints on Rift Models" (1989). School of Geosciences Faculty and Staff Publications. 516.

https://digitalcommons.usf.edu/geo_facpub/516

This Article is brought to you for free and open access by the School of Geosciences at Digital Commons @ University of South Florida. It has been accepted for inclusion in School of Geosciences Faculty and Staff Publications by an authorized administrator of Digital Commons @ University of South Florida. For more information, please contact digitalcommons@usf.edu. 
TECTONICS, VOL.8, NO.6, PAGES 1193-1216, DECEMBER 1989

\section{TOPOGRAPHIC AND VOLCANIC ASYMMETRY AROUND THE RED SEA: CONSTRAINTS ON RIFT MODELS}

Timothy H. Dixon, Erik R. Ivins, and Brenda J. Franklin

Division of Earth and Planetary Sciences, Jet Propulsion Laboratory, California Institute of Technology, Pasadena, California

\begin{abstract}
The Red Sea rift is asymmetric, with the locus of uplift and Tertiary volcanism in Saudi Arabia, 200-400 km east of the present rift axis. One model for this asymmetry involves simple shear extension on an east dipping, low-angle master fault that penetrates the lithosphere. Uplift and volcanism would mark the location where the fault enters the asthenosphere. However, observed seismicity, regional heat flow, and sedimentation are not in accord with this model's predictions. An alternate model involves interaction of upwelling asthenosphere in the early rifting stage with a nearby crustal weak zone such as a suture that controls rift location. In general, the location of the weak zone and subsequent rift will not coincide with the locus of mantle upwelling, leading to several asymmetric rift features. In this model, Tertiary volcanism in Saudi Arabia marks the location of initial upwelling, and uplift is due to crustal thickening associated with magmatic underplating and crustal intrusion. The incipient crustal rift and the locus of mantle upwelling will tend to align as rifting continues and stable seafloor spreading develops, implying relative migration of the lithosphere and asthenosphere. Absolute plate motion models for Africa and strongly asymmetric spreading in the Red Sea are consistent with northeast migration of the incipient rift and adjacent lithosphere with respect to a zone of asthenospheric upwelling.
\end{abstract}

\section{Copyright 1989.}

by the American Geophysical Union

Paper number 89TC01100

0278-7407/89/89TC-01100\$10.00

\section{INTRODUCTION}

Although some continental rifts eventually evolve into ocean basins, evidence from the geologic record suggests that many do not. Studies of the Red Sea may yield insight into factors controlling rift evolution because this region is transitional between a continental rift and an ocean basin. Geologic features associated with the early rift stage may still be preserved on the flanking margins of the Red Sea, while geophysical parameters such as heat flow and seismicity can also be observed in an area undergoing extension.

The Red Sea is markedly asymmetric in several respects. Tertiary volcanism and uplift characterize the eastern flank of the Red Sea (Saudi Arabia). Tertiary volcanism is essentially absent on the western flank (Egypt and Sudan), and average elevation is lower (Figures 1 and 2). The locus of Tertiary volcanism and uplift is roughly $100-300 \mathrm{~km}$ east of the Saudi Arabian coastline, or $200-400 \mathrm{~km}$ east of the present rift axis. Wernicke [1985] advanced a model for this asymmetry involving an east dipping, low-angle lithospheric shear zone. An alternate possibility explored in this paper follows an idea originally proposed by Burke and Dewey [1973] and involves interaction of upwelling asthenosphere during early rifting with a lithosphere of laterally variable strength; a weak zone controls rift location. In general, upwelling will not coincide with the location of the weak zone. Crustal failure and the subsequent rift will then be laterally displaced from the region of initial upwelling. 


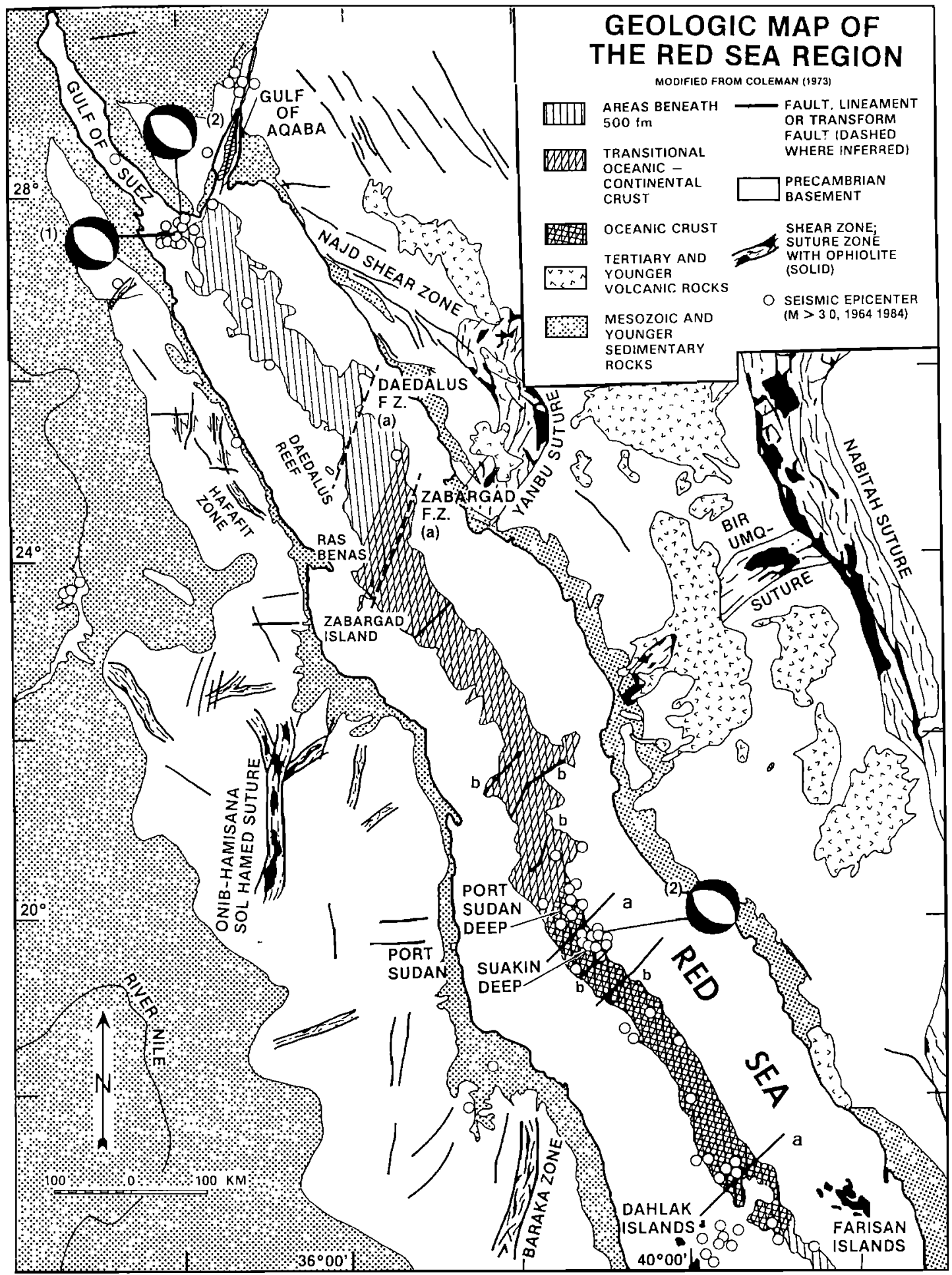

Fig. 1. Generalized geologic map of the Red Sea region, modified from Coleman [1974a]. Major faults, shear zones, or lineaments greater than $50 \mathrm{~km}$ in length are shown from Coleman [1974a] in Saudi Arabia or interpreted from Landsat mosaics in Egypt and Sudan. Suture zones are from Vail [1985], Pallister et al. [1987], and Dixon et al. [1987]. Location of earthquake epicenters with magnitudes greater than 3.0 are shown for the period 1964-1984. Possible transform faults from Coleman [1974a] (labeled "a") and Backer et al. [1975] (labeled "b") are indicated. For the data of Backer et al. [1975] only fracture zones longer than $50 \mathrm{~km}$ are plotted. Earthquake fault plane solutions from (1) McKenzie et al. [1970]; (2) Huang and Solomon [1987]. In the Red Sea axial trough the approximate location of true oceanic crust in the south $\left(16^{\circ} \mathrm{N}\right.$ to $21^{\circ} \mathrm{N}$ [Roeser, 1975; Cochran, 1983]), and transitional oceanic-continental crust $\left(21^{\circ} \mathrm{N}\right.$ to $25^{\circ} \mathrm{N}$ [Cochran, 1983 ; Bonatti, 1985]) is also shown. 


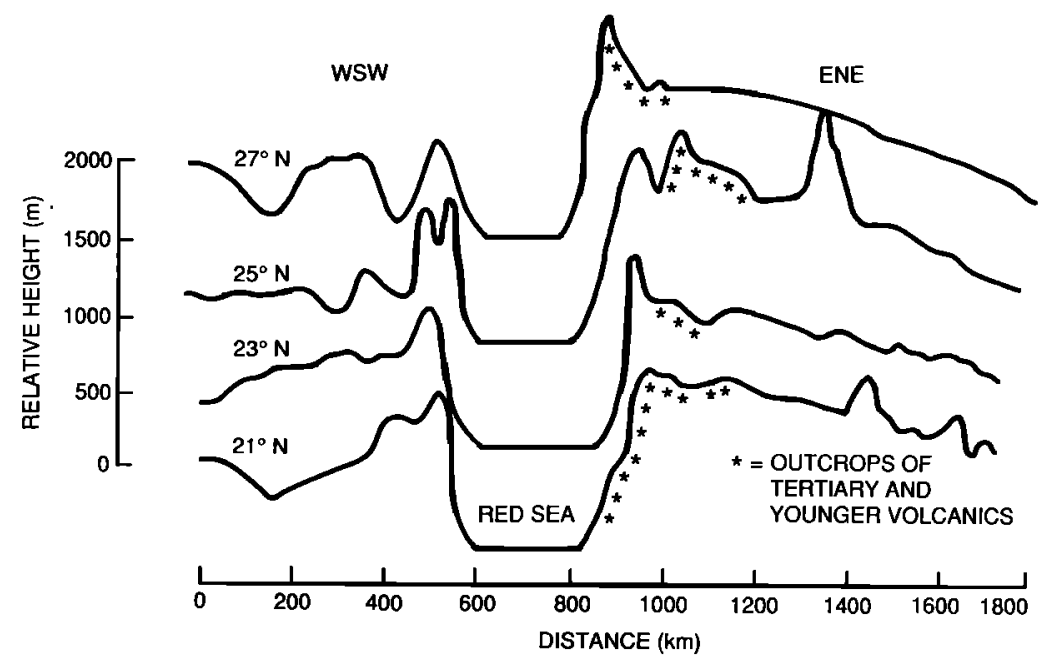

Fig. 2. Topographic profiles for the Red Sea region trending $060^{\circ}$ (WSW-ENE). Indicated latitudes locate where profile crosses the center of the Red Sea. Topographic data from Operational Navigation Charts, U.S. Defense Mapping Agency, scale 1:1,000,000. Volcanic locations from Coleman [1974a]. Note vertical exaggeration.

Models involving structural control of rifts are difficult to test directly because critical evidence may be obscured by later subsidence and sedimentation [Bott, 1982]. Although some evidence for structural control will be presented, the main strategy here is to assume this model as a working hypothesis and assess its feasibility indirectly by exploring some of its consequences through a review of available data. Some implications for rift evolution will also be discussed.

\section{LOW-ANGLE FAULT MODEL FOR RED SEA EXTENSION}

Wernicke [1985] has argued that many features of extensional terrains in the western United States are explained by uniform-sense normal simple shear on a low angle fault extending through the lithosphere. Elevated topography and volcanism occur above the point where the low-angle fault intersects the asthenosphere (Figure 3). Mass conservation does not require dilation and igneous intrusion beneath the brittle layer during extension in the "simple shear" model. In contrast, dilation and intrusion are basic features of the "pure shear" model (Figure 3).

Surface indications of igneous activity associated with Red Sea extension are abundant and provide ample evidence for lower crustal dilatancy by igneous intrusion. Coleman et al. [1983], Bohannon [1986a], and Pallister [1987] describe widespread dike and gabbroic pluton emplacement near the eastern margin of the Red Sea beginning around 30
Ma, approximately coincident with initial continental extension, and continuing to much younger ages. Cochran et al. [1986] report localized magnetic and gravity anomalies in the northern Red Sea, indicating shallow intrusion of individual igneous bodies. High heat flow [Cochran et al., 1986; Buck et al., 1988] suggests that igneous activity extends to recent times. Thus a simple shear model is not required to solve mass balance problems for Red Sea extension.

The simple shear model makes several predictions about evolving rifts that are directly testable in the northern Red Sea, a region of thinned and extending continental crust. Evidence suggests that the model may not apply to this region. First, available heat flow data for the Red Sea and adjacent margins are inconsistent with that predicted by simple shearing [Buck et al., 1988]. Second, the model predicts an asymmetric pattern of seismicity, with earthquakes occurring on steep, west dipping normal faults on the east side of the developing rift (Figure 3). Apparently, no such activity is occurring (Figure 1). In fact, the only seismicity not in the immediate axial trough region in the northern and central Red Sea occurs west of the trough, including some events in the Precambrian shield of Egypt. Third, the simple shear model predicts different sedimentation ages on the east and west margins. Clastic sedimentation on the west margin associated with the "upper crustal breakaway" and related normal faulting should begin earlier than sedimentation on the eastern margin (Figure 3C). In fact, the opposite is observed. Purser and Hotzl [1988] report that early synrift clastics are latest 

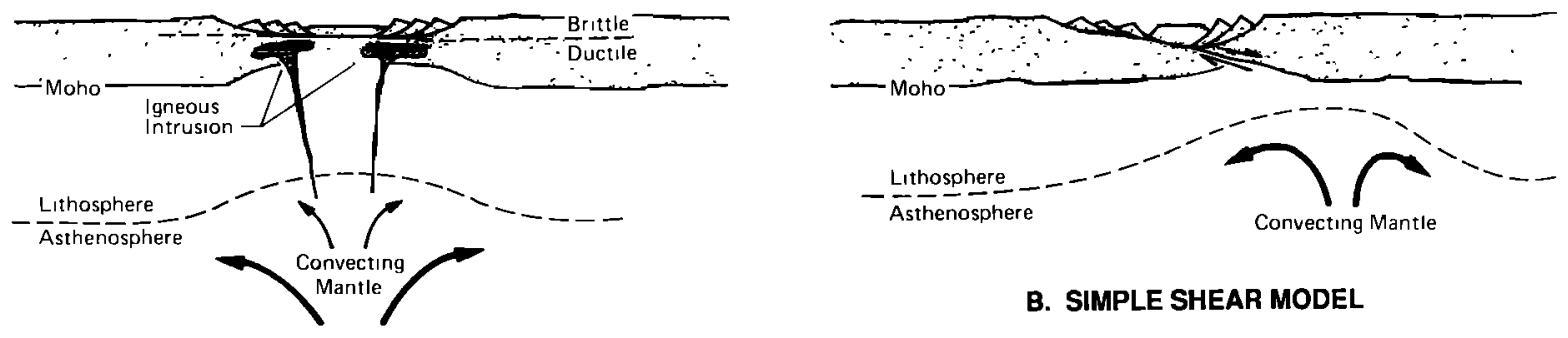

B. SIMPLE SHEAR MODEL

A. PURE SHEAR MODEL

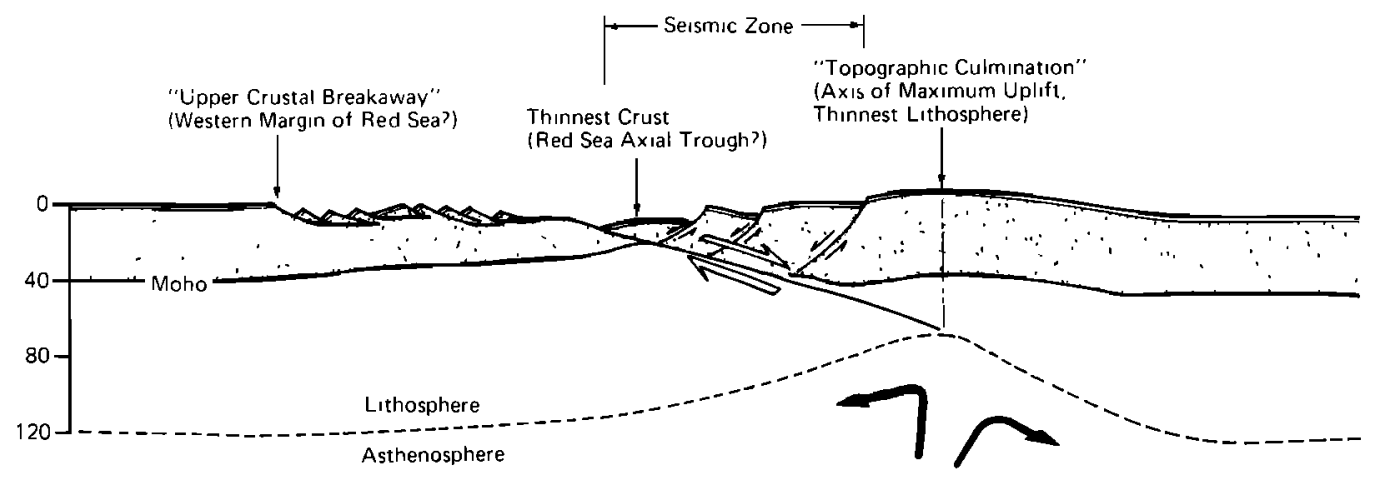

C. SIMPLE SHEAR MODEL FOR THE RED SEA

Fig. 3. (A) Pure shear and (B) simple shear rift models. (C) Simple shear model applied to the Red Sea. The "topographic culmination" (right hand side of figure) occurs in the eastern (Saudi Arabian) part of the rift and marks the locus of maximum uplift and volcanism in the simple shear model. Modified from Wernicke [1985].

Oligocene-Early Miocene in age on the western (Egyptian) margin and Late Oligocene on the eastern (Arabian) margin. Fourth, the model requires that volcanism postdate the first normal faulting associated with the "upper crustal breakaway." In fact, volcanism through much of the region appears to predate deformation [e.g., Bohannon, 1986a]. Finally, the model predicts a migrating and asymmetric locus of crustal strain and deformation. For the northern Red Sea, in the continental extension phase of the model [Wernicke, 1985], abandoned normal faults should be observed on the west side of the basin, and active upper crustal extension should be restricted to the east and central parts of the basin (Figure 3C). However, as pointed out by Joffe and Garfunkel [1987], extension is occurring across the entire width of the northern Red Sea, as indicated by deformation of Pliocene-Quaternary sediments [Phillips and Ross, 1970]. In summary, highly symmetric patterns of heat flow, seismicity, and young deformation in the northern Red Sea, as well as ages of early sedimentation and volcanism, seem to argue against Wernicke's [1985] simple shear model (Figure 3C) and appear to be more consistent with a pure shear mechanism (Figure 3A).

\section{ALTERNATE MODELS FOR RED SEA ASYMMETRY: RELEVANT DATA}

Models for asymmetric topography and volcanism in the Red Sea region should explain, or at least be consistent with, the following six points: (1) Lack of asymmetric seismicity (Figure 1) and heat flow [Buck et al., 1988] implies that asymmetric topography and Tertiary volcanism are due to transient effects during the early rifting stage; (2) heat flow does not appear to be anomalously high in the uplifted continental areas [Gettings et al., 1986], suggesting that thermal effects are not directly responsible for uplift; (3) the general coincidence between areas of maximum uplift and Tertiary volcanism in Saudi Arabia (Figure 2) suggests a causal link between these two features; (4) there appear to be significant differences in mean crustal thickness on either side of the Red Sea. 
Mooney et al. [1985] report that crustal thickness in Saudi Arabia is 38-43 km, while Makris et al. [1981] report that crustal thickness in Egypt is $30-36 \mathrm{~km}$; (5) no rifting occurs in the region of Tertiary volcanism in Saudi Arabia, even though magmatic activity should thermally weaken the crust and upper mantle. Apparently other factors were more important in determining rift location; and (6) the Red Sea has strongly asymmetric spreading rates. Magnetic anomaly patterns indicate that the southwest (African) plate is accreting roughly twice as fast $(9-10 \mathrm{~mm} / \mathrm{yr})$ as the northeast (Arabian) plate (5-6 mm/yr) [Roeser, 1975; Miller et al., 1985; LaBrecque and Zitellini, 1985].

It is axiomatic that tectonic deformation and seismicity tend to be localized by preexisting zones of weakness such as faults. Bassi and Bonin [1988], Dunbar and Sawyer [1989], and Brown and Beaumont [1989] describe rift models where extension is related to a zone of upwelling mantle, but the locus of crustal failure is displaced laterally because a preexisting weak zone controls rift location. An initially strong lithosphere transmits extensional stress laterally. Such models produce well developed axial asymmetries in volcanism and uplift. The following sections describe relevant data in the context of this type of model and the constraints described above.

\section{Volcanism, Underplating, and Uplift}

The first four points listed above (lack of asymmetric heat flow and seismicity, lack of thermal anomalies in uplifted areas, coincidence of uplift and volcanism, and crustal thickness differences) can be explained if uplift and volcanism reflect crustal underplating [McKenzie, 1984] associated with early rifting and mantle upwelling, rather than being a characteristic of present rifting. Bonatti and Seyler [1987] describe a mafic complex in the uplifted crustal section of Zabargad Island. The complex crystallized at high pressure ( $>30 \mathrm{~km}$ depth) and is interpreted as prerift gabbroic underplating of continental crust. A similar process may have underplated the now anomalously high region of Saudi Arabia, an area exceeding $5 \times 10^{5} \mathrm{~km}^{2}$ (Figures 1 and 2).

This hypothesis can be tested with seismic refraction data on crustal thickness. Neglecting erosion and thermal effects and assuming simple Airy isostasy, the thickness $t_{b}$ of an added "basaltic" layer at the base of the crust resulting in uplift $h$ is given by

$$
t_{b}=\frac{h \rho_{m}}{\rho_{m}-\rho_{b}}
$$

where $\rho_{m}$ and $\rho_{b}$ are mantle and "basaltic" densities, respectively (inset, Figure 4). Uplift will occur as long as $\rho_{b}$ is less than $\rho_{m}$, even if $\rho_{b}$ is greater than mean crustal density $\rho_{c}$. Thermal effects are apparently less important in explaining present topography, given observed low heat flow values [Gettings et al., 1986]. Note that the approximate conductive thermal response time of the crust, $\ell^{2} / a x$, where $\ell$ is crustal thickness, $\kappa$ is thermal diffusivity, and a is a constant typically between 2 and 4 [e.g., Morgan and Ramberg, 1987], is about 10-20 million years, while volcanism began by at least $30 \mathrm{Ma}$.

Erosion rates based on fission track data require several kilometers of unroofing since late Oligocene time [Morgan et al., 1985; Omar et al., 1987; Buck et al., 1988]. Since the amount of crust removed by erosion is larger than the observed topographic anomaly (Figure 2), it is clear that erosional effects must be considered. Isostatic rebound will maintain a topographic anomaly for a considerable period despite erosion, assuming that uplift is due mainly to thickened crust. For a constant erosion rate, the average effect on observed topography for a simple Airy model is:

$$
h=h_{0}-R_{\theta} t\left[\frac{\rho_{m}-\rho_{c}}{\rho_{m}}\right]
$$

where $h$ is the presently observed height anomaly, $h_{0}$ is the original anomaly at time $t$, and $R_{e}$ is the erosion rate. A more realistic erosion model accounts for loading of adjacent crust with eroded sediment and allows erosion rate to be proportional to elevation; $R_{e} \approx h / \tau_{e}$, where $\tau_{e}$ is a characteristic time for erosion [Lambeck, 1988, p. 501]. The relative uplift $h$ at any time $t$ for these conditions is:

$$
h=h_{0} e^{-\left[\frac{(1+\beta)\left(\rho_{m}-\rho_{c}\right)}{\rho_{m}}\right] \frac{t}{\tau_{\theta}}}
$$

where the loading factor $\beta$ has values between 0 and 0.5 . Both models are plotted in Figure 4, and give similar results. The present topographic anomaly (taken as $500 \mathrm{~m}$ ) has apparently degraded by about $100-500 \mathrm{~m}$ over the last 20 million years (original anomaly $600-1000 \mathrm{~m}$ ) due to erosion of $1-3 \mathrm{~km}$ of material, implying magmatic underplating totaling 3-7 $\mathrm{km}$ in thickness (equation 1 and Figure 4, inset). This range of values for the postulated underplate thickness beneath Saudi Arabia is similar to the observed difference in crustal thickness on either side of the Red Sea (discussed below).

Available seismic refraction data, though limited, suggest that crustal thickness in Saudi Arabia (38-43 $\mathrm{km}$ [Mooney et al., 1985]) is greater than crustal 


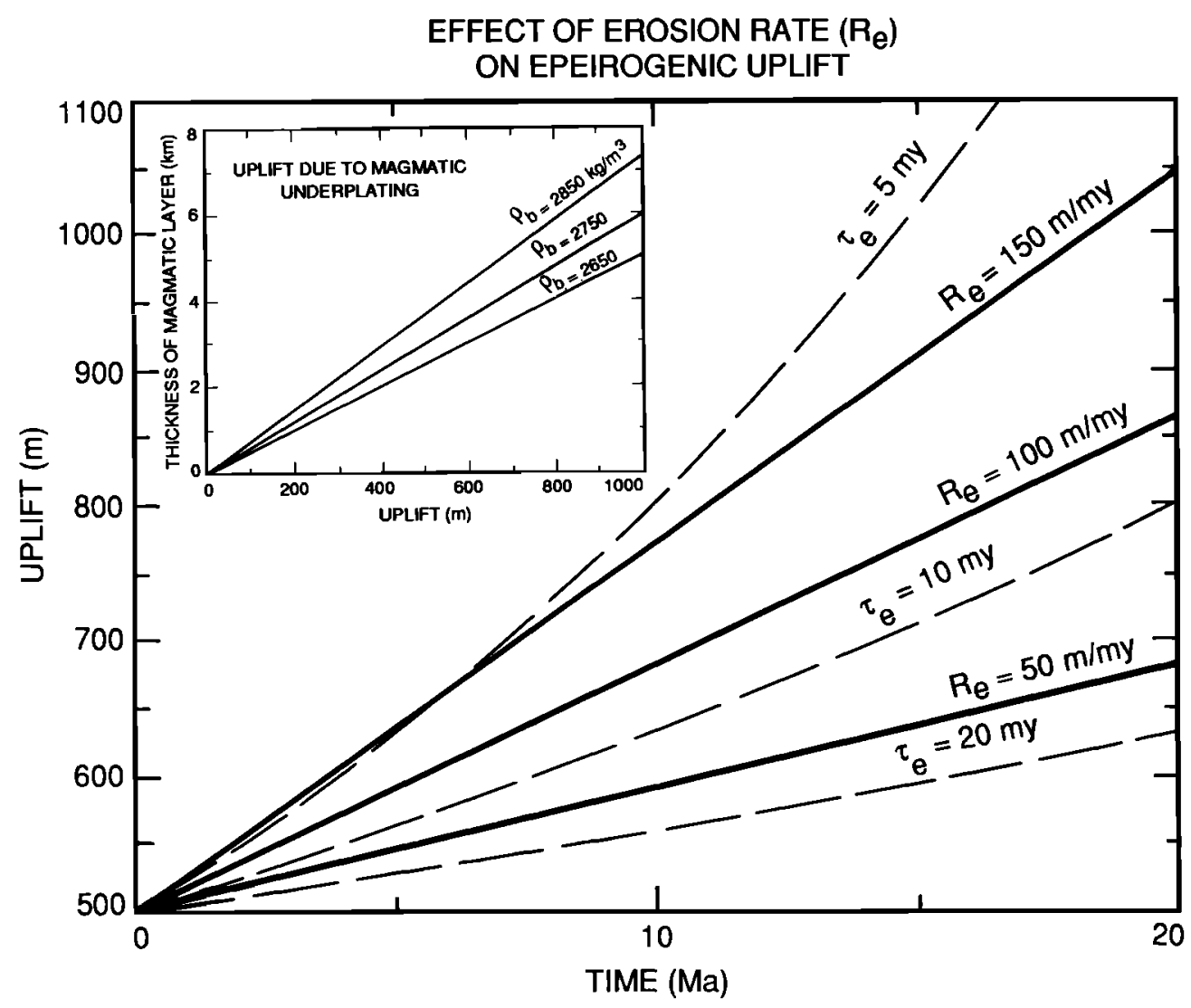

Fig. 4. Effect of erosion on a topographic anomaly (uplift) due to thickened crust assuming Airy isostasy. A present topographic anomaly (h in equations 2 and 3 ) of $500 \mathrm{~m}$ is assumed. For constant erosion rate model (equation 2 ), several rates $\left(\mathrm{R}_{\mathrm{e}}\right)$, in meters per million years are used. For exponential model (equation 3), we have assumed $b=0.3$, and several characteristic times $\left(\tau_{e}\right)$, in million years. Both $\mathrm{R}_{e}$ and $\tau_{e}$ are constrained by fission track data requiring several $\mathrm{km}$ of erosion in post-Oligocene time (see text). Inset shows Airy isostatic models for uplift (h) due to crustal underplating of a mafic layer of thickness $t_{b}$ calculated from equation (1).

thickness in Egypt (30-36 km [Makris et al., 1981]). These differences are probably unrelated to Precambrian crustal evolution processes, because rock assemblages, ages, and isotopic characteristics of the Late Precambrian shield are very similar on both sides of the Red Sea [Dixon and Golombek, 1988]. Since later orogenic episodes, other than Tertiary rifting, are unknown in the region, the crustal thickness differences most likely relate to Tertiaryage, Red Sea-related events. Crustal thickness and topographic data are thus consistent with the hypothesis of Tertiary-age magmatic underplating in Saudi Arabia.

Lower crustal magmatic layers should be manifested by associated volcanic deposits and hypabyssal intrusions of lower volume because continental crust is a strong barrier to mantle-derived mafic melts
[Hildreth, 1981; Herzburg et al., 1983; Crisp, 1984]. Tertiary basaltic lavas and dikes are abundant in Saudi Arabia (Figure 1). Fractionated lavas (dacites and rhyolites) also occur and display chemical and isotopic characteristics suggesting interaction with Precambrian crust [Coleman et al., 1983]. Schmidt and Hadley [1985] describe Oligocene and younger silicic basinal deposits of pyroclastic origin, indicating erosion and redeposition of some volcanic material. Observed Tertiary volcanic rocks in Saudi Arabia therefore give minimum estimates of Tertiary volcanism. They probably manifest a much greater volume of lower crustal magmatic rocks of similar age and in the same general location, consistent with the observation that areas of maximum uplift and Tertiary volcanic outcrops coincide (Figure 2).

If uplift is caused by magmatic underplating, then 
the timing of uplift should be roughly coincident with initiation of magmatic activity, 25-30 Ma (Late Oligocene). This does not conflict with paleosoil evidence [Overstreet et al., 1977: Schmidt et al., 1982], which precludes significant uplift prior to midOligocene, but apparently conflicts with some apatite fission track data. Because of a low annealing temperature $\left(100^{\circ}-150^{\circ} \mathrm{C}\right)$, apatite can record passage through this shallow isotherm during uplift and erosion. However, nearby igneous activity can also cause annealing and resetting of this sensitive mineral. Bohannon [1986a] and Bohannon et al. [1989] report a wide range of apatite fission track ages in Saudi Arabia, including a younger group (14-31 Ma). The youngest age (14 Ma) is interpreted to mark initiation of uplift. However, this is younger than uplift initiation in the Sinai (26.6 $33 \mathrm{Ma}$ [Kohn and Eyal, 1981]) and Egypt (27-30 Ma [Omar et al., 1987]). The Saudi Arabian fission track-based uplift ages also accord fairly well with nearby magmatic ages [Bohannon, 1986a; Pallister, 1987]. Thus the youngest Saudi Arabian apatites may be recording the age of local magmatic pulses rather than the beginning of uplift.

Clastics shed from the uplifted region should appear in the record shortly after uplift begins, initially from erosion of early Tertiary or older sedimentary cover (generating finer-grained clastics) and later from crystalline basement (generating coarser clastics). Coleman [1984] suggested that Late OligoceneEarly Miocene (20-30 Ma) continental clastics were deposited in widespread, intermontane basins. The Shumaysi formation in Saudi Arabia contains pebbly sandstones of probable Oligocene age. Basal conglomerates and sandstones of the Late Oligocene Ayyanah Formation are also recognized [Ahmed, 1972; Schmidt and Hadley, 1985]. Neither of these two units is particularly widespread or thick. Coarse, polymictic conglomerates of Middle or Late Miocene age are also recognized (Bathan formation of Schmidt et al. [1982]) and are also relatively thin (several hundred meters or less in thickness). However, if much of the region has been emergent since $25-30 \mathrm{Ma}$, depositional sinks would not exist except in the developing rift to the west. In this case, thick clastics beneath and within the Miocene evaporites should be deposited in the early Red Sea basin. Well data combined with seismic reflection and refraction suggest that 4-6 km of sediments exist in the Red Sea shelves and coastal plains [Ahmed, 1972; Coleman, 1974]. While $3 \mathrm{~km}$ or more of this section consists of Miocene evaporites, abundant intercalated clastic material has been documented, including thick Lower Miocene conglomerates and sandstones [Ahmed, 1972; Miller and Barakat, 1988]. This may represent the main depositional sink for several kilometers of
post-Late Oligocene erosion implied by the fission track data [e.g., Omar et al., 1987; Buck et al., 1988].

Active Versus Passive Rift Models: The Role of Upwelling Mantle

The stresses contributing to extensional strain are obviously a key factor in rift evolution. Two end member causes for rifting have been suggested on the basis of the nature of driving stresses [Sengor and Burke, 1978]. Active rifts are caused by stresses associated with convecting mantle at the base of the lithosphere, leading to uplift of overlying lithosphere [Spohn and Schubert, 1983] and/or traction at its base [Morgan, 1972; Reches and Schubert, 1987]. Passive rifting is caused by plate-driving forces outside the immediate area of the rift. Thinned lithosphere leads to asthenospheric upwelling, and uplift and volcanism are secondary processes. Active and passive rifts might be distinguished by the relative timing of uplift, volcanism, and rifting. In active rifts, uplift and volcanism precede normal faulting and rifting, while the reverse is true for passive rifts.

Most rifts probably evolve under a combination of processes. Crough [1983] and Ramberg and Morgan [1984] pointed out that domed areas do not always rift and suggested that combined active and passive mechanisms may be required to initiate rifting. The Red Sea has been modeled as both an active rift [e.g., Falvey, 1974; Kinsman, 1975; Lowell et al., 1975; Morgan et al., 1985] and a passive rift [Bohannon et al., 1989]. Clearly, there is some ambiguity in fitting the geological characteristics of the Red Sea into a simple active or passive rift framework. However, Africa is surrounded on three sides by spreading ridges and should be in a general state of compression [Bott, 1982]. This plate configuration has existed at least through Tertiary time. Models calling for purely passive rifting of the Red Sea would therefore appear to be incomplete. Geological data on the timing of uplift, extension, and volcanism in the Red Sea region are summarized in Figure 5. Uplift has been previously discussed; extension and volcanism are discussed below.

Extension. The age of seafloor initiation in the region is fairly well known from the magnetic anomaly record. However, estimating the beginning of continental extension is more difficult, as most of the relevant geologic record is hidden in the subsided margins. Oceanic crust in the southern Red Sea definitely began forming by $5 \mathrm{Ma}$ [Roeser, 1975] and possibly earlier, 10-13 Ma [Le Pichon and Gaulier, 1988]. Full spreading rates are about $1.5-1.6 \mathrm{~cm} / \mathrm{yr}$ [Roeser, 1975; Miller et al., 1985]. The earliest 


\section{AGE OF INITIAL EXTENSION, IGNEOUS ACTIVITY AND UPLIFT AROUND THE RED SEA}

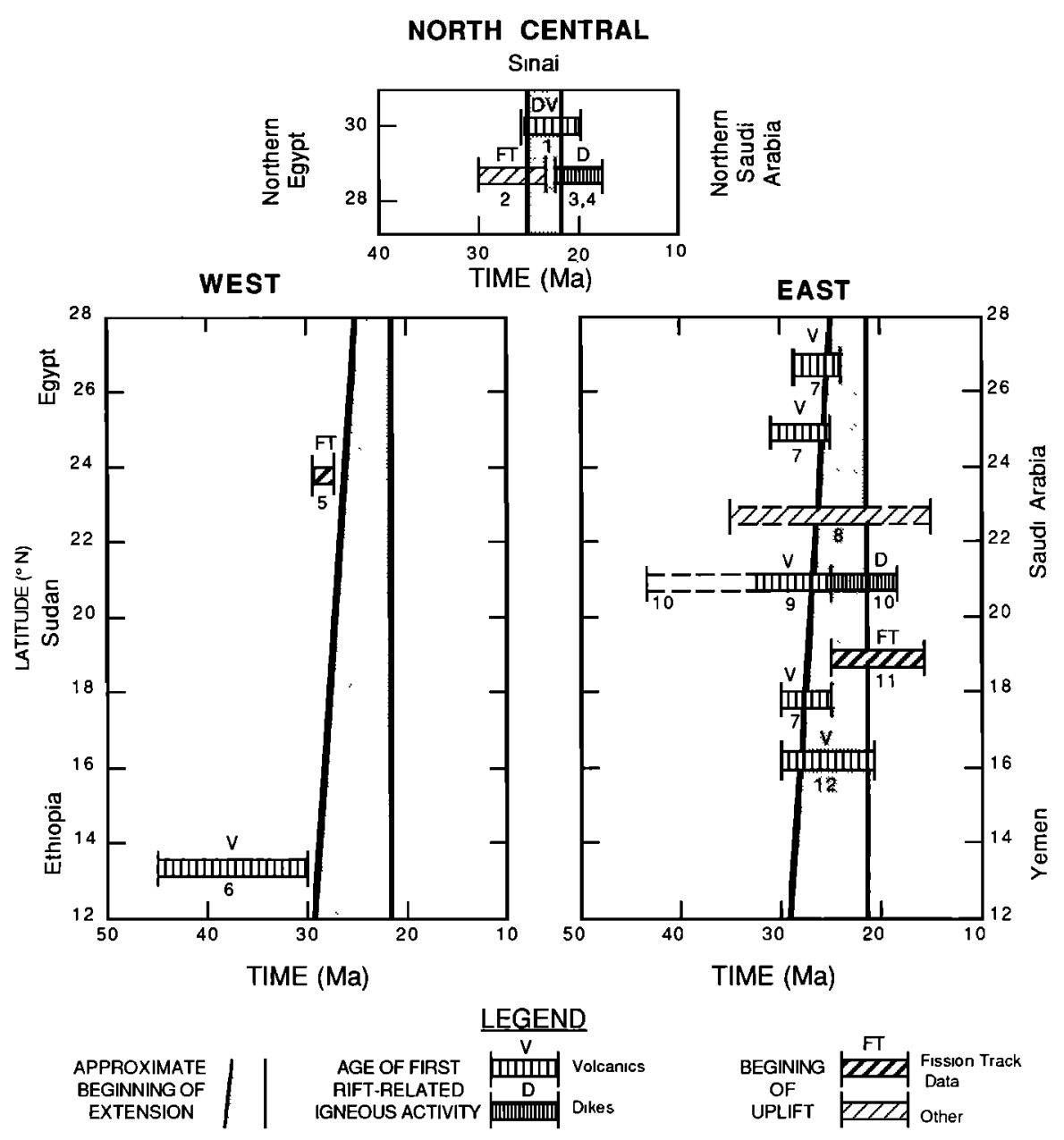

Fig. 5. Relative timing of initial extension, igneous activity, and uplift around the Red Sea. Extension in the northern Red Sea began about 22-25 Ma, while extension in the southern Red Sea began around 23-29 Ma (see text). Width of bar reflects measurement uncertainty or scatter of ages. For igneous and uplift data, sources are 1, Steinitz et al. [1978]; 2, Kohn and Eyal [1981]; 3, Steinitz et al. [1980]; 4, Bartov et al. [1980]; 5, Omar et al. [1987]; 6, Mohr [1983]; 7, Coleman et al. [1983]; 8, Stacey and Agar [1985]; 9, Brown et al. [1984]; 10, Pallister [1987]; 11, Bohannon [1986a], Bohannon et al., [1989]; and 12, Capaldi et al. [1983].

isochrons (and maximum width of the Red Sea axial trough) occur at about $17^{\circ} \mathrm{N}$. The Red Sea is usually interpreted as a northward propagating rift, since thinned continental crust floors the northern Red Sea [Cochran et al., 1986], heat flow decreases northward [Girdler and Evans, 1977; Ben Avraham and Von Herzen, 1987], and the depth of normal fault focal mechanisms increases northward [Huang and Solomon, 1987].
Motion on the Dead Sea-Gulf of Aqaba transform fault provides a constraint on the beginning of extension in the northern rift. This fault has a total offset of about $105 \mathrm{~km}$, based on detailed mapping of offset units [Freund et al., 1970]. Additional $(25-30 \mathrm{~km})$ extension occurred in the Gulf of Suez [Colletta et al., 1988; Steckler et al., 1988]. Offset across the Gulf of Aqaba began after mid-Miocene (20 Ma), because dikes in southern Sinai of age $20 \pm 2 \mathrm{Ma}$ are 
offset by the same amount as Precambrian units [Bartov et al., 1980; Eyal et al., 1981]. Assuming the Gulf of Aqaba offset occurred at $1.0 \mathrm{~cm} / \mathrm{yr}$ (the current rate) then $105 \mathrm{~km}$ offset would require 10.5 Ma. Bayer et al. [1988] suggest activation of the Aqaba transform after about $14 \mathrm{Ma}$. Joffe and Garfunkel [1987] favor transform motion averaging $0.5-0.6 \mathrm{~cm} / \mathrm{yr}$ on the Dead Sea fault during the last 17-20 Ma. Taking this latter age and adding $5.0 \mathrm{Ma}$ for $30 \mathrm{~km}$ extension in the Gulf of Suez at the same rate suggests that extension in the north began no earlier than about 22-25 Ma. This is consistent with the earliest Miocene age of the first synrift sediments in the Gulf of Suez [Evans, 1988; Steckler et al., 1988].

Extension at $17^{\circ} \mathrm{N}$ (where the oldest magnetic anomalies are recorded) probably started earlier. Northwest trending mafic dikes intruded into continental crust near the Red Sea margin probably mark an early extension phase and are dated at 18-28 Ma [Bohannon, 1986a; Pallister, 1987; Sebai, et al., 1987; Voggenreiter et al., 1988]. Bohannon [1986a] suggested that intense normal and detachment faulting associated with early extension in Saudi Arabia probably occurred between 23-25 Ma but may have begun as early as $29 \mathrm{Ma}$. We therefore bracket the beginning of continental extension in the south at 23-29 Ma.

Volcanism Volcanism in the northern and central Red Sea began by early Miocene time [Coleman, 1974b; Bartov et al., 1980; Baldridge et al., 1985]. In Saudi Arabia, Oligocene flows as old as $32 \mathrm{Ma}$ (Brown et al. [1984]; and E. A. Dubray and D. B. Stoeser [1986], as quoted by Bohannon et al. [1989]), and mafic plutons with K-Ar cooling ages as old as $30 \mathrm{Ma}$ [Coleman et al., 1979] have been described. Pallister [1987] describes a single age of $43 \mathrm{Ma}$, but there are no additional data to support volcanism as old as this in Saudi Arabia. In Yemen, Trap Series basalts were widely erupted between 30.0 and 22.1 Ma [Capaldi et al., 1983]. Tertiary volcanism in Ethiopia began about 45-50 Ma [Davidson and Rex, 1980; Mohr, 1983]. These data suggest that mafic volcanism preceded extension by several million years in some regions adjacent to the Red Sea (Figure 5). Bohannon [1986a] reached the same conclusion for one area in southwestern Saudi Arabia based on detailed mapping.

Uplift, however, more or less coincided with the early stages of continental extension (Figure 5). The timing of volcanism, uplift, and extension thus supports neither purely active nor purely passive rifting. Early volcanism noted above does, however, imply an association between upwelling mantle and rift initiation (see also Morgan et al. [1985]). In the model to be described it will be assumed that extensional stress is derived from a combination of passive and active mechanisms.

The age and extent of earliest mafic volcanism in a region can be used to infer minimum age and regional trends of initial mantle upwelling. The location of Cenozoic mafic volcanics, as well as the age of earliest volcanism in a given area (defined in the figure caption), are plotted for northeast Africa-Arabia in Figure 6. Three important observations can be made from this figure. First, there is a clear north trending belt of mafic Cenozoic volcanism that diverges from the north-northwest trend of the Red Sea. Second, the amount of volcanism decreases northward from a maximum in the Afar region, suggesting either that asthenospheric upwelling is more vigorous in this region and decreases northward or that volcanism has been active longer in the south, allowing a greater volume of volcanics to accumulate. Third, the age of earliest Cenozoic volcanism within a given region also decreases northward, from about $45 \mathrm{Ma}$ in northern Ethiopia, to $30 \mathrm{Ma}$ in Yemen and west central Saudi Arabia, to about $20-25 \mathrm{Ma}$ in the Sinai. This age trend is opposite that expected for a fixed mantle "hotspot." The African plate is thought to be moving slowly northeast in a hotspot reference frame [Gordon and Jurdy, 1986], and a fixed zone of upwelling asthenosphere would produce a southwest younging age trend. The observed northward propagation of volcanism implies northward propagation of upwelling asthenosphere at a rate significantly faster than the motion of the African plate. The rate of propagation inferred from the trend in volcanic ages is about the same as the rate of northward rift propagation (Figure 5), suggesting a relation between upwelling asthenosphere and rifting. The fact that volcanism in several areas appears to lead extension by several million years (Figure 5) is significant in this regard.

\section{Thermal Controls on Lithospheric Strength}

It is puzzling that the region in Saudi Arabia subject to volcanism beginning about $30 \mathrm{Ma}$ was not itself the locus of extension. Lithospheric strength is strongly controlled by temperature [Brace and Kohlstedt, 1980], and this thermally "preweakened" zone would seem to be the logical place for extension to begin. Obviously, additional factors must exist to limit thermal weakening in the region where surface volcanics are exposed and promote extension in the adjacent rift.

Camp and Roobol [1989] compiled histograms of volcanic ages in Saudi Arabia. They suggest that although volcanism began about $30 \mathrm{Ma}$, most activity occurred in the last 10 million years, implying that initial upwelling (at $\approx 30 \mathrm{Ma}$ ) may not have been vig- 


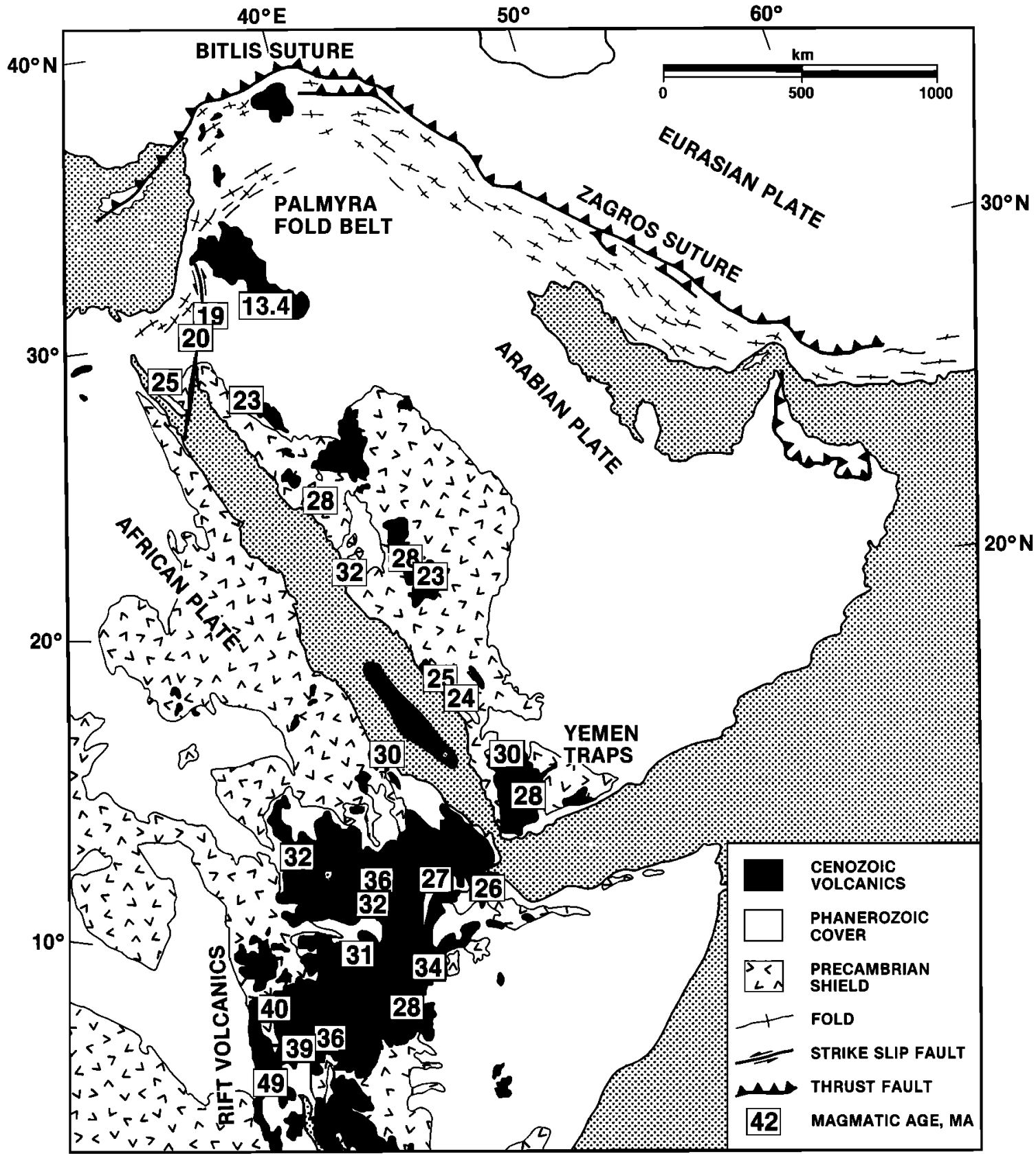

Fig. 6. Areas of Cenozoic mafic volcanism for the Red Sea-East African Rift region, modified from Camp and Roobol [1989]. Regions of seafloor spreading-related basaltic volcanism in the Indian Ocean and Gulf of Aden are omitted. Volcanism younger than $10 \mathrm{Ma}$ is present in most of the areas showi. Ages shown are the oldest reported volcanism within a $1^{\circ}$ square if at least two independent and consistent data points are available. Data have been further filtered for reliability by plotting only data taken after 1970, requiring that these data have reported uncertainties of less than $10 \%$ and, if available in the original publication, requiring the fraction of radiogenic ${ }^{40} \mathrm{Ar}$ to be greater than $10 \%$ [e.g., Tabor et al., 1985]. If both individual ages and isochrons were compiled, only the isochron ages have been used. Note the trend of generally decreasing ages to the north. Data sources: Arno et al. [1980]; Barberi et al. [1980]; Brown et al. [1984]; Capaldi et al. [1983]; Coleman et al. [1977]; Davidson and Rex [1980]; Kazmin et al. [1980]; Pallister [1987]; Steinitz et al. [1978]; Zanettin et al. [1980]. 
orous enough to heat the overlying crust and lithosphere significantly. Alternately, the thermal response of the crust and lithosphere may have been slow compared to the rate of migration over the region of hot asthenosphere. The time $t$ available for thermal interaction is just $w / r$, where $w$ is the width of the hot upwelling zone and $\mathrm{r}$ is the plate migration rate. For $w=200 \mathrm{~km}$, the approximate width of the Tertiary volcanic field in Saudi Arabia (Figures 1 and 6 ), and $\mathrm{r}=2 \mathrm{~cm} / \mathrm{yr}$, the mean absolute plate motion rate for Africa during Tertiary time [Gordon and Jurdy, 1986], $t=10$ million years. This is similar to the conductive thermal response time of the crust, implying that more exact treatments are required to assess the importance of crustal heating during passage over the hotspot.

Assuming that rifting began where the Red Sea is widest and where oceanic crust is best developed $\left(\approx 16^{\circ}-19^{\circ} \mathrm{N}\right)$, the broad scale pattern of asthenospheric upwelling suggested by Figure 6 and its influence on Red Sea rifting is generally consistent with our understanding of thermal controls on lithospheric strength. Rifting apparently began where thermal influence was maximum, in the south, and has since migrated generally northward. However, further extension along the trend of the modern Red Sea (north-northwest) diverged somewhat from the more northerly trend of the volcanic belt shown in Figure 6. Other thermal or mechanical factors must have led to greater weakness in the region that actually rifted.

Lithospheric strength models [Brace and Kohlsted, 1980] combined with simple heat conduction theory can give some insight here. In particular, we need to demonstrate that lithospheric strength is not reduced to negligible values when a region like west central Saudi Arabia is subject to volcanism at the levels implied by Figure 6 and that, for similar assumptions, there are plausible mechanisms for large strength reductions in adjacent areas that can lead to rifting.

For advection-dominated heat transfer (magmatic intrusion throughout the lithosphere, including the middle and upper crust), total plate strength would rapidly decrease and rifting should occur. However, continental crust can be a strong barrier to mantlederived magma because the lower density of the crust relative to mafic melt hinders high-level emplacement, and the lower melting point of most continental crust promotes assimilation and freezing of more refractory mantle melts in the lower crust. Mantle-derived mafic magma will therefore tend to pond at the base of continental crust unless the crust is actively extending [Hildreth, 1981; Herzberg et al., 1983], leading to the underplating model described previously. This suggests that conduction models may be useful for approximating the thermal effects of a sill-like intrusion at the base of the crust on the strength of the middle and upper crust.

In the brittle upper crust, frictional sliding on preexisting fractures relieves deviatoric stress. Average stress is controlled by both the friction coefficient and effective pressure. The friction coefficient $t_{s}$ is relatively constant and independent of temperature and mineralogy, with serpentine and some clays important exceptions [Byerlee, 1978]. The brittle strength criterion can be approximated by [Sibson, 1983]:

$$
\tau=\mathrm{f}_{\mathrm{s}} \sigma_{\mathrm{n}} \approx 0.75 \sigma_{\mathrm{n}}
$$

where $\tau$ is the shear stress and $\sigma_{n}$ the effective normal stress. Below the brittle-ductile transition depth, temperature reaches a critical activation value and ductile (power law) creep occurs at lower stresses relative to brittle failure, thus controlling maximum stress. The ductile flow law has the form

$$
\dot{\varepsilon}=A\left(\sigma_{1}-\sigma_{3}\right)^{n} e^{-Q / R T}
$$

where $\varepsilon$ is the strain rate, $R$ is the gas constant, $T$ is the absolute temperature, and $A, n$, and $Q$ are experimentally determined material constants which are strong functions of mineralogy (Table 1). Equations (4) and (5) define strength profiles for the lithosphere that can be used as guides to investigate thermal effects. Kirby [1983] and Lynch and Morgan [1987] give a more complete discussion and compilation of material constants.

The strength profiles are sensitive to strain rate, composition, and geothermal gradient. A mean strain rate of $10^{-14} / \mathrm{s}$ (range $10^{-13}-10^{-15} / \mathrm{s}$ ) was used in the models (Figure 7). Red Sea extension is limited to a fairly narrow rift zone and has rapidly proceeded to oceanic crust formation, implying relatively high strain rates, compared to, for example, the mean strain rate of $10^{-15} / \mathrm{s}$ used to model extension in the Basin and Range [Morgan et al., 1986] and East African rift [Shudofsky et al., 1987].

Quartz is one of the weakest of common crustal minerals and will control overall strength if present in amounts greater than a few volume percent. However, mafic rocks dominate the Precambrian surface exposures in the Saudi Arabian shield [Gettings et al., 1986], and it is likely that they control the rheology of the lower crust for at least some regions.

The geothermal gradient will be affected by the time-dependent cooling of any lower crustal intrusion. An estimate of far-field thermal conduction into the middle and upper crust from a thick sill at the base 
TABLE 1. Material Constants Used in Power Law Creep Flow Models

\begin{tabular}{llcccr}
\hline $\begin{array}{l}\text { Depth } \\
\text { Regime }\end{array}$ & $\begin{array}{l}\text { Rock, } \\
\text { Mineral }\end{array}$ & $\begin{array}{c}\mathrm{A}, \\
\mathrm{MPa}^{-\mathrm{n}} \mathrm{s}^{-1}\end{array}$ & $\mathrm{n}$ & $\begin{array}{c}\mathrm{Q}, \\
\mathrm{kJ} / \mathrm{mol}\end{array}$ & Source \\
\hline $\begin{array}{l}\text { Upper } \\
\text { crust }\end{array}$ & $\begin{array}{l}\text { wet } \\
\text { quartzite }\end{array}$ & $5.75 \times 10^{-5}$ & 2.44 & 160 & $\begin{array}{r}\text { Koch et al. } \\
{[1980]}\end{array}$ \\
$\begin{array}{l}\text { Lower } \\
\text { crust }\end{array}$ & diabase & $6.12 \times 10^{-2}$ & 3.05 & 276 & $\begin{array}{r}\text { Caristan } \\
{[1982]}\end{array}$ \\
$\begin{array}{l}\text { Upper } \\
\text { mantle }\end{array}$ & olivine & $6.31 \times 10^{-4}$ & 3.5 & 533 & $\begin{array}{r}\text { Kirby } \\
{[1983]}\end{array}$ \\
\hline
\end{tabular}

of the crust can be made by considering the timedependant decay of an instantaneous step increase in temperature at the depth of intrusion (taken as $35 \mathrm{~km}$, the base of the crust; Figure 7C). Details of the heat conduction solution are given in the appendix. The corresponding strength estimates of the crust at various times (Figures 7B and 7D) assume an initial surface heat flow of $75 \mathrm{~mW} / \mathrm{m}^{2}$, intermediate between typical values for a stable Precambrian shield (40-60 $\left.\mathrm{mW} / \mathrm{m}^{2}\right)$ and an active volcanic province $(90-110$ $\mathrm{mW} / \mathrm{m}^{2}$ ). The strength models suggest that, although upper mantle and thus total lithospheric strength are reduced, the net decrease in strength due solely to conductive crustal heating may not be large even after 5-10 million years. This suggests that the crust and lithosphere in Saudi Arabia retained some strength during the limited heating implied by the patchy surface volcanics in central and northern Saudi Arabia erupted during the period 20-30 Ma; extension is not inevitable, assuming relatively weak passive rifting forces and limited heating. We conclude that the crust can apparently survive a single pulse of magmatism resulting in emplacement of a thick sill at the base of the crust.

However, when the assumption of conductiondominated heat transfer breaks down, for example if extensive middle and upper crustal mafic intrusion occurs, crustal strength quickly becomes negligible, and rifting should ensue. It is difficult to model this directly, but some idea of the sensitivity of crustal strength to advective heat transport via magmatic emplacement can be gained by considering a conductionlimited case that would be a lower bound. This model is similar to the one developed in Figure 7, but we now calculate a geotherm assuming that the lower boundary (the Moho) is maintained at a higher temperature, perhaps representative of the case where asthenospheric upwelling is more vigorous and mag- matic activity reoccurs periodically. The corresponding geotherm can be estimated simply by superposing the original steady state geotherm and the time-dependent heating of a half-space at original temperature $T_{0}$ when the lower boundary is maintained at a higher temperature $T_{s}$, again taken as the liquidus temperature of basalt at the appropriate pressure:

$$
T=T_{0}+\left(T_{s}-T_{\partial}\right)[\operatorname{erfc}(z / 2 \sqrt{\kappa t})]
$$

where $\mathrm{z}$ is distance, $\mathrm{t}$ is time, and erfo is the complementary error function. Results are shown in Figure 8. Heat is transferred into the middle and upper crust more quickly relative to the model shown in Figure 7, significantly reducing crustal strength within 5 million years, even though heat transfer is limited by comparatively slow conduction. Clearly, additional advective heat transport would reduce crustal strength much more rapidly and presumably could lead to rifting even in the presence of weak extensional stresses.

We have no direct data on why the Red Sea formed where it did, but an important observation is that the spatial density of Tertiary mafic dikes in Saudi Arabia increases toward the Red Sea, beginning about $100 \mathrm{~km}$ from the coast [Blank, 1977; Coleman et al., 1977; Schmidt et al., 1982; Coleman, 1984; Bohannon, 1986a]. Such dikes are essentially absent on the western Red Sea margin. Bohannon [1986b] showed that seismic refraction data require a significant part of the crust beneath the Red Sea shelves to be composed of mafic igneous material intruded during a preseafloor spreading stage of rifting. These observations are consistent with a relation between high-level igneous activity and the occurrence of significant extensional strain. Factors promoting such high-level igneous activity remain to be determined. 

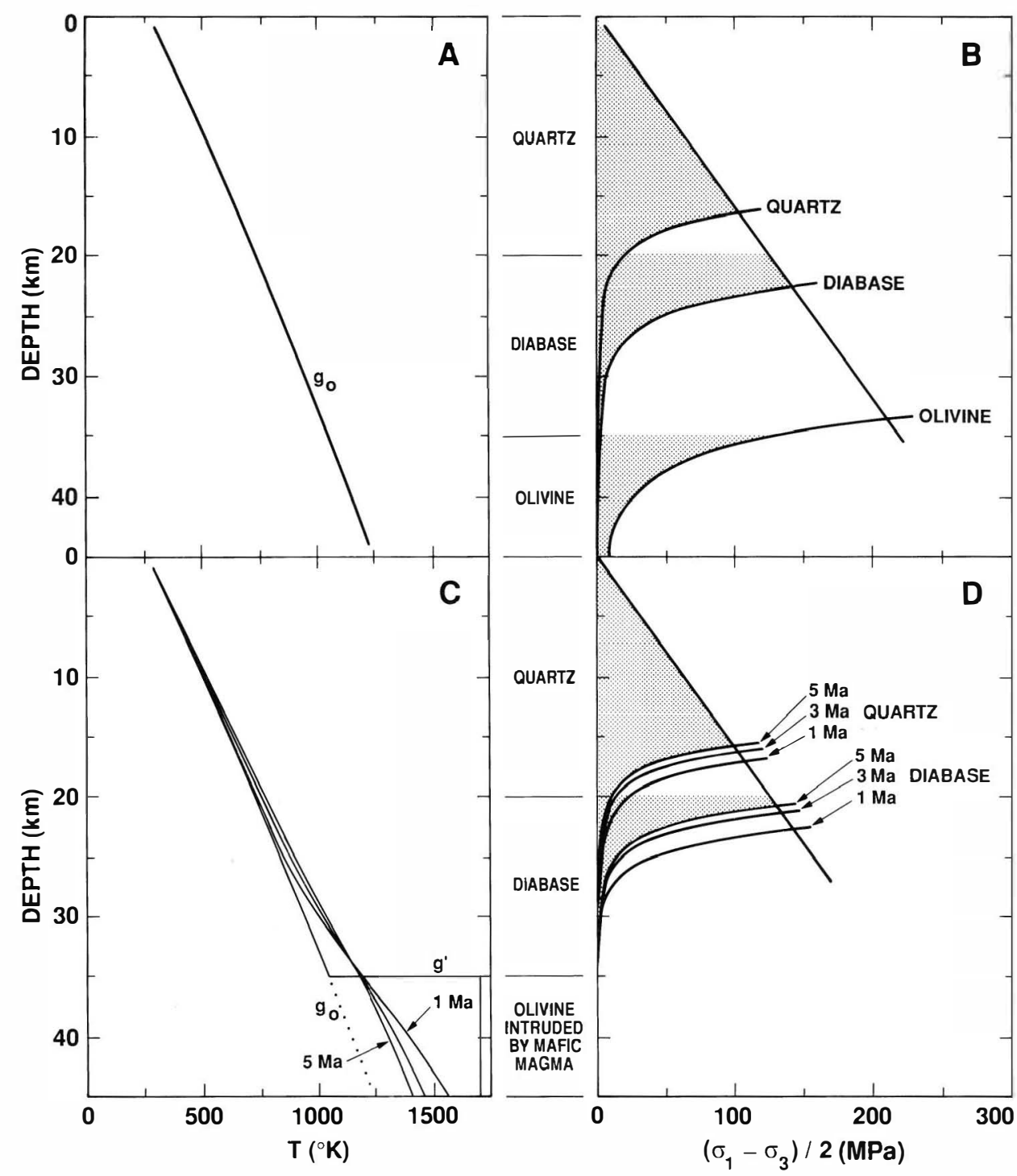

Fig. 7. Geotherms and corresponding lithospheric strength profiles before (Figures 7A and B) and after (Figures 7C and D) intrusion of a thick sill at the base of the crust. Steady state geothern, go, (Figures 7A and C) calculated according to equation (24) of Lachenbruch and Sass [1977], assuming surface heat flow $=75 \mathrm{~mW} / \mathrm{m}^{2}$, thermal conductivity $=2.75 \mathrm{~W} / \mathrm{m} \mathrm{deg}$, characteristic depth $=10 \mathrm{~km}$, and heat generation $=2.0 \mathrm{~W} / \mathrm{m}^{3}$. Geotherm g' (Figure 7C) represents an idealized step change immediately after intrusion of sill. Transient thermal effects 1 million, 3 million, and 5 million years after intrusion of the sill are superimposed on the original geotherm go in Figure 7C. Cooling curves evolve from g' back to go, as described in the appendix. Strength profiles calculated according to equations (4), (5), and material constants in Table 1. Brittle strength curve assumes water saturation. Quartzrich material is assumed for the upper crust, diabase is assumed for the lower crust, and olivine is assumed for the upper mantle, with depth boundaries as shown. Strain rate for ductile strength curves (Figure 7B and D) is $10^{-14} / \mathrm{s}$; strain rates of $10^{-13} / \mathrm{s}$ and $10^{-15} / \mathrm{s}$ were tested and do not change results significantly. Stippled area in Figure 7D shows strength after 5 million years; times longer than this do not show significant strength changes. 


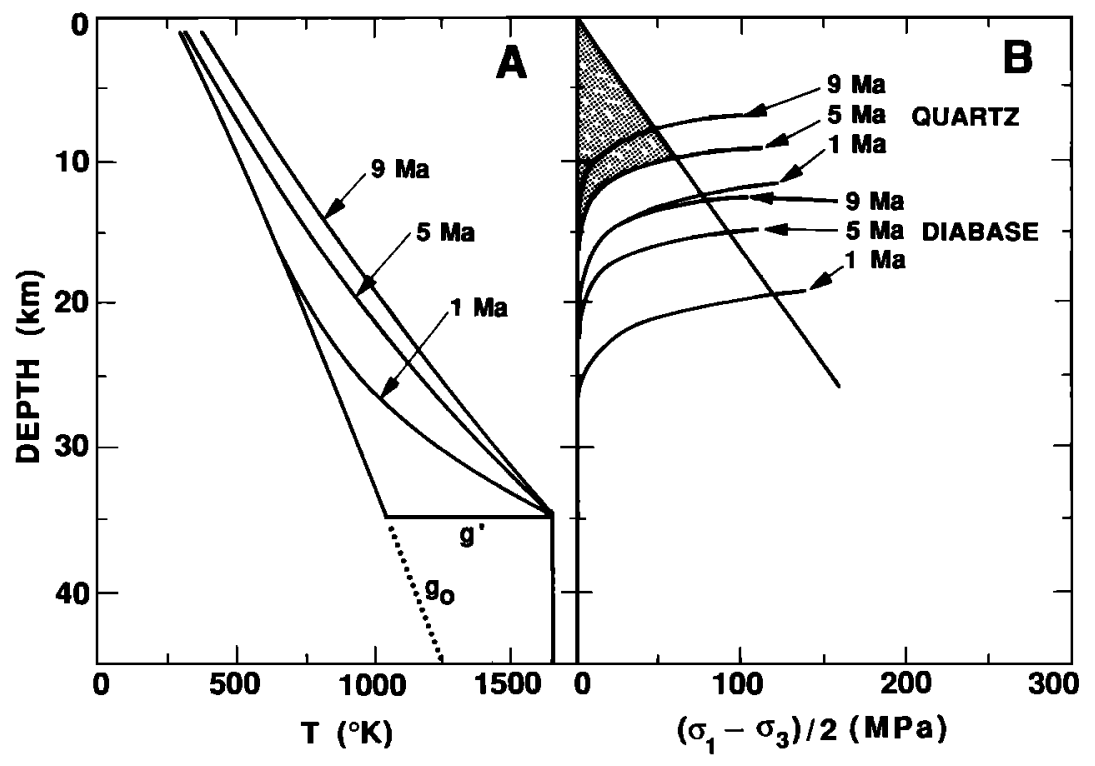

Fig. 8. Similar to Figure 7, except the geotherm is calculated assuming a thermal boundary at the base of the crust maintained at a constant higher temperature (equation (6)). To is taken as the temperature at the base of the crust prior to intrusion. Values of To closer to average crustal temperature result in faster heating of the middle and upper crust and more rapid strength reduction. Stippled area represents strength after 5 million years, for comparison to Figure 7D.

Asymmetric Spreading and Migration of the Incipient Rift Relative to Underlying Asthenosphere

Upwelling asthenosphere laterally displaced from the locus of crustal extension can produce some axially asymmetric features during initial rifting. However, as stable seafloor spreading develops, it seems likely that upwelling asthenosphere and the rift axis will tend to align vertically. Vink [1984] noted that the Iceland hotspot, initially located beneath Greenland, channeled material to, and finally migrated beneath, the Mid-Atlantic Ridge. Weinstein and Olson [1989] noted that hotspots are preferentially located near divergent plate boundaries and suggested that mantle plumes associated with hotspots would tend to be entrained into the upwelling flow beneath spreading centers.

Continued heating of continental crust from below will lead to significant weakening and possible rifting in the region directly above the upwelling asthenosphere on time scales less than 10 million years, as discussed in the last section. The fact that the region in Saudi Arabia where 20-30 Ma volcanics are exposed did not rift requires either that asthenospheric upwelling wained shortly after it started or that the lithosphere moved with respect to the asthenosphere, removing the affected crust from the zone of greatest heating. This section describes evidence for realign- ment of the lithosphere with respect to the asthenosphere. This motion brought the incipient rift more closely into alignment with the locus of upwelling.

Magnetic anomaly patterns indicate that spreading in the southern Red Sea is highly asymmetric [Roeser, 1975]. Although many oceanic ridges have slight $(\approx 10 \%)$ spreading rate asymmetries, the large (factor of 2) magnitude of the Red Sea spreading rate asymmetry is surprising. Stein et al. [1977] presented a model for asymmetric spreading involving migration of a ridge with respect to its asthenospheric source. In this model, northeast motion of the Red Sea spreading ridge with respect to its source would result in the trailing (southwest) plate accreting material faster than the advancing (northeast) plate, as observed (Figures 9A and 9B). Since the migration rate from absolute plate motion models $(1-3 \mathrm{~cm} / \mathrm{yr}$; see below) is of the same order as the total spreading rate $(1.5 \mathrm{~cm} / \mathrm{yr})$, it is easy to imagine the large difference in the half-spreading rates being generated in this manner.

Africa's relative motion in a hotspot reference frame is slowly northeast and appears to have been steady for the last $60 \mathrm{Ma}$, with rates of about 1-3 $\mathrm{cm} / \mathrm{yr}$ [Solomon and Sleep, 1974; Gordon and Jurdy, 1986]. We are most interested in absolute plate motion for the period 20-5 Ma, that is, prior to establishment of the Red Sea as a well-defined plate 
A

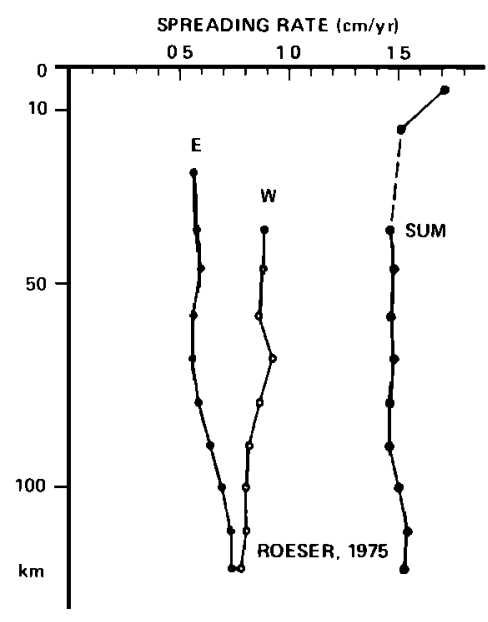

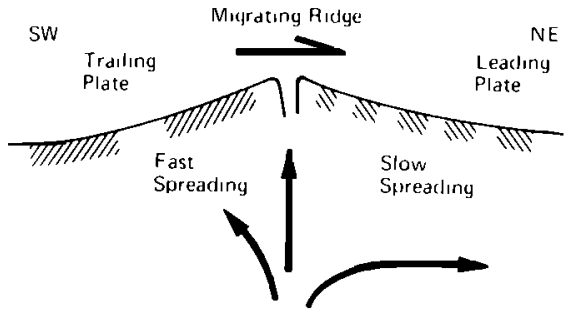

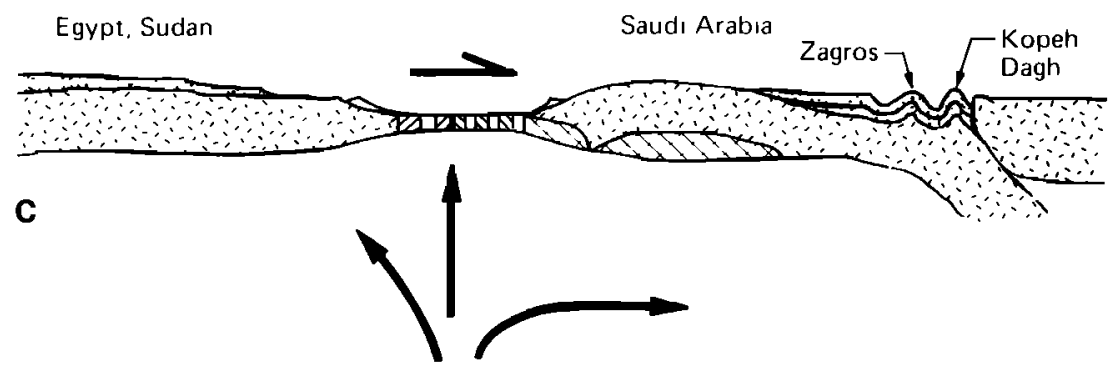

Fig. 9. Evidence for northeast migration of the incipient rift and adjacent lithosphere relative to (fixed?) upwelling asthenosphere includes (A) highly asymmetric spreading, as evidenced by magnetic anomalies [from Roeser, 1975]. These data are most easily interpreted as resulting from migration of the spreading center with respect to its underlying asthenospheric source, with the trailing plate accreting material roughly twice as fast as the leading plate (B); and (C) the Tertiary deformation of the $\mathrm{Za}$ gros and Kopeh-Dagh belts in Iran to the northeast. Rocks of similar age in Egypt, Sudan, and regions farther west and southwest are essentially undeformed.

boundary. By $20 \mathrm{Ma}$ the zone of upwelling asthenosphere had apparently migrated well north of the Afar region, assuming that mafic volcanism can be used to indicate such activity (Figure 6). If we further assume relatively fixed hotspot-like behavior for this north trending zone of asthenospheric upwelling after $20 \mathrm{Ma}, 2 \mathrm{~cm} / \mathrm{yr}$ northwest migration of the Afro-Arabian plate over the asthenosphere produces $400 \mathrm{~km}$ of relative motion in $20 \mathrm{Ma}$, roughly the distance between the locus of Tertiary volcanism in Saudi Arabia and the south central Red Sea axial trough (Figure 1). Rotation of Arabia about the absolute pole of rotation for Africa [Gordon and Jurdy, 1986] places most of the field of Tertiary volcanics in Saudi Arabia close to the zone of current seafloor spreading and transitional crust in the southern and central Red Sea axial trough (Figure 1). This strongly suggests a common mantle origin.
A simple trend of decreasing volcanic ages to the southwest across the Arabian Shield from 20 Ma to 5 Ma is not observed. Epp [1984] discussed reasons why simple age-distance trends may not occur for oceanic hotspot volcanism, including lateral channeling of magma and mechanisms that enable continued volcanism after passage over the hotspot. Perhaps more relevant here are factors such as the slow rate of migration of the African plate, the fact that the zone of upwelling does not appear to be stationary and finally, the bias that continental crust can exert on mantlederived magmatism. Thus it is unlikely that age-distance trends for Tertiary volcanics in Saudi Arabia can lead us much beyond the crude generalizations made above.

In summary, asymmetric magnetic anomalies and absolute plate motion models imply northeast migration of the incipient rift and adjacent lithosphere rela- 
tive to a zone of upwelling asthenosphere. This is consistent with the observation that Tertiary compressional deformation adjacent to the rift, apparently accommodating some fraction of the additional crust created during Red Sea rifting, is restricted to the northwest-trending Zagros and Kopeh-Dagh fold belts in Iran northeast of the rift (Figures 6 and 9C).

\section{A MODEL FOR RED SEA ASYMMETRY}

Consideration of the data described in preceding sections and its implications lead to the following model for Red Sea asymmetry, sketched in Figure 10:

1. Mantle upwelling begins beneath Saudi Arabia about $30 \mathrm{Ma}$ as upwelling asthenosphere associated with the Afar hotspot migrates northward.

2. Magmatic underplating and some surface volcanism occur, with limited crustal heating. Total underplate thickness will eventually reach $\approx 5 \mathrm{~km}$, leading to $\approx 1 \mathrm{~km}$ of uplift by $10-20 \mathrm{Ma}$; differential erosion will reduce this to the $\approx 500 \mathrm{~m}$ average anomaly observed at present.

3. Slow northeast migration of the African plate eventually positions a crustal weak zone (e.g., a suture or zone of quartz-bearing lower crust) over the locus of upwelling. Extensional stresses cause rifting and crustal thinning. Igneous activity will be centered on the region of maximum crustal thinning due to volume conservation, reflecting interaction of upwelling mantle and the original crustal weak zone, and leading to rapid thermal weakening of the middle crust, the only remaining strong part of the lithosphere (the lower crust and upper mantle were already thermally weakened by passage over the hot spot).

4. Continued magmatic activity in the presence of extensional stresses (either plate boundary stresses or traction associated with upwelling asthenosphere) leads to formation of oceanic crust in the southern Red Sea.

Asymmetric uplift and volcanism are largely artifacts of the early rift stage in this model, consistent with the observation made earlier that patterns of heat flow and seismicity are axially symmetric for both the northern and southern Red Sea. The regions of uplift and Tertiary volcanism also coincide in this model, as observed. Volcanism in Saudi Arabia may continue for some time after passage over the hotspot but will eventually decline relative to seafloor spreading-related magmatism in the Red Sea axial trough.

A low-angle fault extending through the entire lithosphere is not required in this model. The original upper crustal weak zone could itself be a low-angle
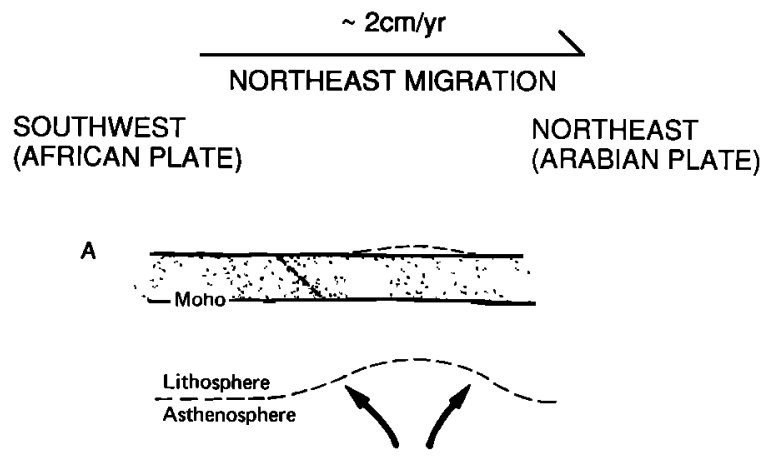

B

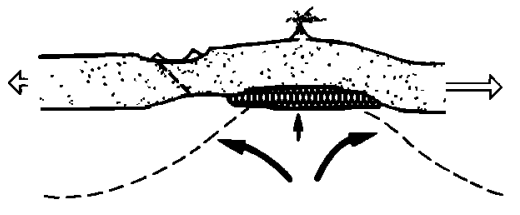

c

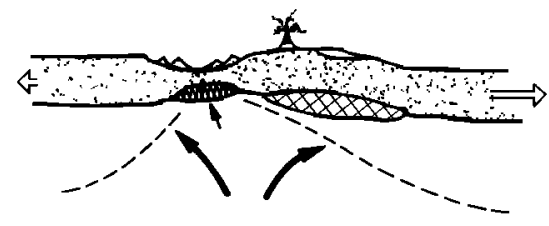

D

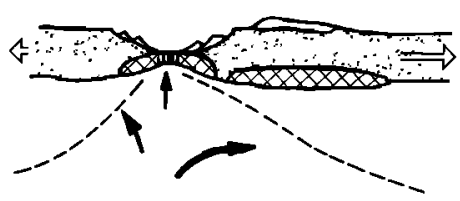

Fig. 10. Schematic model for asymmetric volcanism and topography around the Red Sea. (A) Mantle upwelling occurs at a location that does not coincide initially with a crustal weak zone ultimately controlling rift location. (B) Emplacement of mafic magma, mainly in the lower crust of the northeast (Saudi Arabian) plate, causes crustal thickening, doming and some surface volcanism. Extensional stresses lead to crustal thinning centered at the crustal weak zone. (C) Crustal thinning leads to magma emplacement in the lower crust in the vicinity of the weak zone, locally raising isotherms, weakening the crust and promoting further extension at that location. Migration of the incipient rift and adjacent lithosphere relative to the asthenosphere occurs, due either to reorientation of mantle convection or, as shown, migration of overlying lithosphere relative to a fixed asthenospheric hotspot. (D) The current configuration. Asthenospheric upwelling and the locus of rifting are aligned. Thickened crust and Tertiary volcanics on the northeastern (Arabian) plate mark the locus of initial upwelling. 
feature (e.g., an older thrust fault) but need only affect the brittle upper crust. Extension occurs predominantly by pure shear below the brittle-ductile transition in the model, and the resulting dilation and igneous intrusion are important in heating and weakening the middle and upper crust.

\section{DISCUSSION}

\section{Evidence for Preexisting Weaknesses}

As much as $200 \mathrm{MPa}$ ( $2 \mathrm{kbar}$ ) may be required to initiate rifts in intact continental rocks [Bott, 1981; Bott and Mithen, 1983]. This is higher than the stresses available from doming $(\approx 100 \mathrm{MPa}$ or $1 \mathrm{kbar}$ [Bott and Kusznir, 1979]) and also higher than stresses likely available from passive rift mechanisms, based on observed stress levels within plate interiors [McGarr and Gay, 1978] and plate driving force models [Solomon et al., 1980], both arguments suggesting maximum stresses of the order of $50 \mathrm{MPa}$ (500 bars). There are large uncertainties in the above values, but one plausible conclusion is that crustal weaknesses play an important role in rift initiation. A necessary condition for the model described above is the presence of a crustal weak zone near the locus of initial mantle upwelling. Evidence for this is now discussed.

The importance of mechanical anisotropy in the crust has long been recognized [e.g., Seigel, 1950; Etheridge, 1986]. Zoback and Zoback [1980] demonstrated that reactivation of preexisting faults during extension was favored over breaking intact rock over a fairly wide range of stress orientations. Wilson [1966, 1969], Burke and Dewey [1973], Sykes [1978], and Turcotte [1983] noted the tendency of rifts to initiate along older structural boundaries such as sutures. Control of rifting by older crustal structures has been suggested for the Baikal rift [Logatchev and Florensov, 1978; Zamarayev and Ruzhich, 1978], the East African rift [McConnell, 1972], the Benue Trough [Maurin et al., 1986], and the Rio Grande rift [Tweto, 1979; Kelley, 1979]. Hutchinson et al. [1985] and Ratcliffe et al. [1986] suggest that Paleozoic thrust faults in the Appalachians were reactivated during Mesozoic extension, resulting in the modern Atlantic ocean. Cheadle et al. [1987] demonstrate that preexisting basement thrust faults in the western U.K. continental shelf were also reactivated during Mesozoic extension. Doser [1988] shows seismic evidence indicating that the Baikal rift is propagating along a major preexisting basement weakness.

Unfortunately, evolution to a mature rift stage (ocean basin) can obscure evidence of the role of older crustal structures as rift edges subside and sediments accumulate [Bott, 1971, 1982]. We must use indirect arguments to assess the possible role of older crustal structures in the evolution of the Red Sea.

The crust now bisected by the Red Sea formed in late Precambrian time with collision and accretion of island arcs [e.g., Ries et al., 1983; Vail, 1985; Pallister et al., 1987]. Two features of arc/accretion complexes may lead to anomalously weak regions that could be exploited by later tectonic events: (1) crustalscale granitic batholiths, leading to quartz-dominated rheology in the lower crust; and (2) the suture zones marking the boundaries between originally separate terrains or plates. Arguments presented earlier on crust and upper mantle strength during passage over hot asthenosphere suggest that variations in crustal strength may have an important influence on rift initiation. Upper mantle strength diminishes because of thermal effects, regardless of other compositional and mechanical factors. Crustal strength then becomes the major variable. Given sufficient time, heating would also reduce crustal strength, but we need only consider the transient conditions of the early rift stage. The strength contrast between a crustal section composed primarily of quartz-bearing material (e.g., a batholith that comprises most of the crust) and a region characterized by mafic compositions below, for example, $15 \mathrm{~km}$ can be significant (see Figure 7).

Thrusts and other faults within suture zones could also act as weak zones, depending on their strength contrast with the surrounding crust, their size, and their orientation. Ivins et al. [1989] demonstrate that frictional contrast plays a large role in fault reactivation and suggest that extensional reactivation of preexisting thrust faults is likely under a wide range of conditions. Schmidt et al. [1982] note that Red Searelated normal faults in Saudi Arabia follow northerly Precambrian structures, remaining parallel to the north-northwest trending Red Sea by en echelon left stepping. Dixon et al. [1987] suggest that two north trending suture zones in northeast Sudan and northern Ethiopia (the Onib-Hamisana and Baraka zones; Figure 1), parts of which may extend into Saudi Arabia, influenced the geometry of the northnorthwest propagating Red Sea rift. The suture zones, originally lithospheric-scale discontinuities, may continue to act as weak zones, due to the presence of serpentinite and weak, clay-bearing fault gouges with resulting effects on brittle strength. Serpentine may have frictional strength considerably lower than other minerals [e.g., Byerlee, 1978; Morrow et al., 1982; Weeks et al., 1988] and also releases large amounts of water upon heating, potentially increasing pore fluid pressure and 
reducing effective pressure [Raleigh and Paterson, 1965; Murrell and Ismail, 1976]. Suture zones mapped in northeast Sudan [Dixon et al., 1987; Dixon and Golombek, 1989] and Saudi Arabia [Pallister et al., 1987] are notable for the widespread occurrence of serpentinites. This may explain why another major Precambrian structure, the $>1000-\mathrm{km}-$ long Najd shear zone, was not exploited by the rift. This feature was developed primarily as a strike slip fault zone [e.g., Stern, 1985] and does not contain appreciable serpentinite.

\section{Implications for Rift Evolution}

Wood [1983] described several continental rifts that apparently jumped closer to their asthenospheric source. However, the best documented example of the effect of lithosphere-asthenosphere migration on a developing rift is the Cretaceous Benue Trough - Tertiary Cameroon Line volcanic belt in West Africa [Fitton, 1980]. Here, the lithosphere and developing rift migrated farther from the asthenospheric source, the reverse of the Red Sea case. This migration effectively cut the rift off from its volcanic roots and apparently led to a cessation of rifting in the Benue Trough. Plate motion direction (with respect to a hotspot or other locus of asthenospheric upwelling) may therefore be an important factor in rift evolution. If the rift remains close to upwelling asthenosphere, a lengthy period of crustal magmatism can ensue, with consequent thermal weakening of the crust and upper mantle, potentially leading to full rupture of the continental lithosphere and ocean formation.

The rapid crustal thinning expected in a mechanically weak zone that localizes extension may also be important in focusing magmatism and promoting rifting. Widespread igneous intrusion apparently occurred near the present Red Sea margin [LaBrecque and Zitellini, 1985; Bohannon, 1986a,b; Pallister, 1987; Bonatti and Seyler, 1987]. Cochran [1981] suggests that the magnetic quiet zone adjacent to the continental shelves in the Gulf of Aden represents the effect of pervasive magmatism during the incipient rift stage. Gravity and seismic refraction data suggest abrupt thinning of the shield crust near the Red Sea coast [Qureshi, 1971; Brown and Girdler, 1982; Mooney et al., 1985]. These observations imply the following general scenario. Crustal thinning associated with initial extension is localized along a mechanically weak zone such as a suture. Assuming pure shear extension beneath the brittle-ductile transition zone in the crust, asthenospheric upwelling will tend to occur beneath the thinnest crust, leading to localized crustal intrusion, heightened geotherms, and thermal weakening of the lithosphere in that particular region (Figures 3 and 10; Kusznir and Park [1987]; Keen [1987]). This weakening in turn promotes continued localized extension and crustal thinning. A feedback mechanism is established involving localized extension, crustal thinning, and increasingly focused magmatism. If extension continues, full lithospheric rupture and seafloor spreading will occur. Thus the mechanically weak zone not only influences initial rift location but can also play a role in subsequent rift evolution by focusing magmatic activity. This suggests a cause for the mechanism proposed by Burke and Dewey [1973] wherby mantle plumes exhibit a "probing action," picking out overlying crustal weaknesses. Sutures or other mechanically weak zones may therefore be another critical feature of "successful" (i.e., ocean-forming) rifts.

\section{CONCLUSIONS}

1. Topographic and volcanic asymmetry around the Red Sea are important constraints on rift models.

2 . Topographic and volcanic asymmetry around the Red Sea can be explained with a model involving asthenospheric upwelling beneath a lithosphere of laterally variable strength. A weak zone (e.g., a suture or region with quartz-bearing lower crust) may have controlled the location of rifting. In general, the locus of upwelling and the crustal weak zone will not be spatially coincident, at least initially. The incipient rift and the locus of upwelling may align if rifting continues to the stage of seafloor spreading, either by upper plate motion, reorientation of mantle convection, or both. Early rift-related volcanism marks the locus of initial upwelling and magmatic underplating. The amount of uplift can be quantitatively linked to the amount of magmatic underplating or crustal intrusion and consequent crustal thickening via simple models involving Airy isostasy and constant or exponentially decreasing erosion.

3. Absolute plate motion models, the pattern of asymmetric seafloor spreading in the southern Red Sea, and post-Oligocene deformation in marginal zones to the northeast suggest that the incipient Red Sea rift and adjacent lithosphere migrated northeast over a relatively fixed zone of asthenospheric upwelling. Absolute plate motion with respect to upwelling asthenosphere may be an important factor in rift evolution.

4. Preexisting weak zones may also be an important factor in rift evolution. They localize extension and crustal thinning and thereby focus magmatism, in effect "capturing" the upwelling asthenosphere and promoting initiation of seafloor spreading. 


\section{APPENDIX: CONDUCTIVE SOLUTION FOR "INSTANTANEOUS" MAGMATIC EMPLACEMENT AT DEPTH $Z_{0}$}

The thermal profile evolution shown in Figure 7C is obtained via solutions of the thermal diffusion equation:

$$
\frac{\partial \theta}{\partial t}=k \frac{\partial^{2} \theta}{\partial z^{2}}
$$

with boundary conditions:

$$
\begin{gathered}
\theta(0, t)=0 \\
\theta \mid z \rightarrow \infty, t)=T_{\text {mantle }}-T_{\text {surface }}
\end{gathered}
$$

and initial conditions:

$$
\theta(\mathrm{z}, 0)=f(\mathrm{z})
$$

where it is assumed that $\mathbf{T}_{\text {mantle }}$ and $\mathbf{T}_{\text {surface }}$ are constant deep mantle and crustal surface temperatures, respectively, $\boldsymbol{k}$ is the thermal diffusivity $(0.01$ $\mathrm{cm}^{2} / \mathrm{s}$ ), and $z$ is the vertical coordinate directed downward from the crustal surface. The system (A1) is solved using an application of Fourier's Sine Integral Theorem, and the solution is:

$$
\begin{aligned}
\theta(\mathrm{z}, \mathrm{t}) & =\frac{2}{\pi} \int_{0}^{\infty} e^{-\lambda^{2} \mathrm{kt}} \sin \lambda z \int_{0}^{\infty} f(s) \sin \lambda s d s d \lambda \\
& =\gamma \int_{0}^{\infty}\left[e^{-\pi\left(s-z^{2} \gamma^{2}\right.}-e^{-\pi\left(s+z^{2} \gamma^{2}\right.}\right] f(s) d s
\end{aligned}
$$

with $\gamma \equiv 1 / \sqrt{4 \pi \kappa} \mathrm{t}$.

The solution (A2) was used in a two-step procedure. First, initial profiles $f_{1}(z)$ were examined that closely matched the Lachenbruch and Sass [1977] models with appropriate surface heat flux and which evolved slowly, varying only a few degrees over a 20 Ma time scale. Second, at the depth to the top of the mafic intrusion, $z_{0}$, a Heavyside step function $\mathrm{T}_{\text {mant } \ell e} \mathrm{H}\left(\mathrm{z}-\mathrm{z}_{\mathrm{o}}\right)$ is linearly combined with $f_{1}(\mathrm{z})$ to form the initial profile g', shown in Figure 7C.

At the base of the diabasic brittle-ductile transition zone, temperature increases by $\Delta \mathrm{T}$ at a distance $\ell$ above the intruded mafic layer. The solutions (Figure 7C) demonstrate that at $z=z_{0}-\ell$, the base of the diabasic seismogenic zone, temperature changes are about $40^{\circ} \mathrm{C}$, or less, in $2 \mathrm{Ma}$ and reach no more than $60^{\circ}-70^{\circ} \mathrm{C}$ in $5 \mathrm{Ma}$ for $\ell=12-15 \mathrm{~km}$. For $\ell \approx 20 \mathrm{~km}$, the values of $\Delta \mathrm{T}$ (at the same times) are factors of 2-3 smaller. The corresponding changes in crustal strength (Figure 7D) show that, while the depth of the diabasic seismogenic zone shallows during $5 \mathrm{Ma}$ of upward heat conduction, the diabase layer is never completely absorbed into the ductile deformation regime.

Acknowledgments. We thank Matthew Golombek for helpful discussions and a review of an earlier version of this manuscript. Don Wise and Dwight Schmidt provided very helpful reviews. This research was supported by the Land Processes Branch, National Aeronautics and Space Administration (NASA), and was performed at the Jet Propulsion Laboratory, California Institute of Technology, under contract to NASA.

\section{REFERENCES}

Ahmed, S.S., Geology and petroleum prospects in eastern Red Sea, Am. Assoc. Pet. Geol. Bull., 56, 707-719, 1972.

Arno, V., M.A. Bakashwin, A.Y. Bakor, F. Barberi, A. Basahel, G.M. DiPaola, G. Ferrara, M.A. Gazzaz, A. Giuliani, M. Heikel, G. Marinelli, A.O. Nassief, M. Rose, and R. Santacroce, Recent Volcanism within the Arabian plate: Preliminary data from Harrats Hadan, and Nawasif-Al Buqum, in Geodynamic Evolution of the Afro-Arabian rift system, Rome, Italy Accademia Nazionale dei Lincei, p. 629-643, 1980.

Backer, H., K. Lange, and H. Richter, Morphology of the Red Sea central graben between Subai Islands and Abul Kizan, Geol. Jahrb. D-13, 79$123,1975$.

Baldridge, W.S., Y. Bartov, and G. Steinitz, Miocene magmatism of Sinai related to the opening of the Red Sea, EOS: Trans. AGU, 66, 1062, 1985.

Barberi, F., G. Capaldi, P. Gasperini, G. Marinelli, R. Santacroce, R. Scandone, M. Treuil, and J. Varet, Recent basaltic volcanism of Jordan and its implications on the geodynamic history of the Dead Sea shear zone, in Geodynamic Evolution of the Afro-Arabian rift system: Rome, Italy Accademia Nazionale dei Lincei, p. 667-683, 1980.

Bartov, Y., G. Steinitz, M. Eyal, and Y. Eyal, Sinistral movement along the Gulf of Agaba--Its age and relation to opening of the Red Sea, Nature, $285,220-221,1980$.

Bassi, G., and J. Bonin, Rheological modeling and deformation instability of the lithosphere under extension, Geophys. J. 93, 485-504, 1988.

Bayer, H.J., H. Hotzl, A.R.Jado, B. Roscher, and W. Voggenreiter, Sedimentary and structural evo- 
lution of the northwest Arabian Red Sea margin, Tectonophysics 153, 137-151, 1988.

Ben-Avraham, Z., and R.P. Von Herzen, Heat flow and continental breakup: the Gulf of Elat (Aqaba), J. Geophys. Res., 92, 1407-1416, 1987.

Blank, H. R., Aeromagnetic and geologic study of Tertiary dikes and related structures on the Arabian margin of the Red Sea, Red Sea Research 1970-1975, Saudi Arabian Dir. Gen. Min. Res Bull. 22, G1-G18, 1977.

Bohannon, R.G., Tectonic configuration of the western Arabian continental margin, southern Red Sea, Tectonics, 5, 477-499, 1986a.

Bohannon, R.G., How much divergence has occurred between Africa and Arabia as a result of the opening of the Red Sea, Geology. 14, 510-513, $1986 \mathrm{~b}$.

Bohannon, R.G., C.W. Naeser, D.L. Schmidt, and R.A. Zimmerman, The timing of uplift, volcanism and rifting peripheral to the Red Sea: A case for passive rifting?, J. Geophys. Res., 94, 1683$1701,1989$.

Bonatti, E., Punctiform initiation of seafloor spreading in the Red Sea during transition from a continental to an oceanic rift, Nature, 316, 33-37, 1985.

Bonatti, E., and M. Seyler, Crustal underplating and evolution in the Red Sea rift: uplifted gabbro/gneiss crustal complexes on Zabargad and Brothers Islands, J. Geophys. Res. 92, 12,80312, 821, 1987.

Bott, M.H.P., Evolution of young continental margins and formation of shelf basins, Tectonophysics, 11, 319-327, 1971.

Bott, M.H.P., Crustal doming and the mechanism of continental rifting, Tectonophysics, 73, 1-8, 1981.

Bott, M.H.P. The mechanism of continental splitting, Tectonophysics, 81, 301-309, 1982.

Bott, M.H.P., and D.P. Mithen, Mechanisms of graben formation-the wedge subsidence hypothesis, Tectonophysics, 94, 11-22, 1983.

Bott, M.H.P., and N.J. Kusznir, Stress distributions associated with compensated plateau uplift structures with application to the continental splitting mechanism, Geophys. J. R. Astron. Soc., 6, 451-459, 1979.

Brace, W.F., and D.C. Kohlstedt, Limits on lithosphere stress imposed by laboratory experiments, J. Geophys. Res. 85, 6248-6252, 1980.

Brown, C., and R.W. Girdler, Structure of the Red Sea at $20^{\circ} \mathrm{N}$ from gravity data and its implications for continental margins, Nature, 298, 51-53, 1982.

Brown, G.F., D.L. Schmidt, and A.C. Huffman, Geology of the Arabian peninsula shield area of western Saudi Arabia, U.S. Geol. Surv. Open File Rep. OF-84-203, 217 p., 1984.

Brown, K.C., and C. Beaumont, Kinematic models of the midcontinent rift beneath Lake Superior constrained by GLIMPCE data, EOS: Trans $A G U, 70,275,1989$.

Buck, W.R., F. Martinez, M.S. Steckler, and S.R. Cochran, Thermal consequences of lithospheric extension: pure and simple, Tectonics, 7, 213234, 1988.

Burke, K., and J.F. Dewey, Plume-generated triple junctions: Key indicators in applying plate tectonics to old rocks, J. Geol., 81, 406-433, 1973.

Byerlee, J.D., Friction of rocks, Pure Appl. Geophys., 116, 615-626, 1978.

Camp, V. E., and M. J. Roobol, The Arabian continental alkali basalt province: Part 1: Evolution of Harrat Rahat, Kingdom of Saudi Arabia, Geol. Soc. Am. Bull., 101, 71-95, 1989.

Capaldi, G., P. Manetti, and G.B. Piccardo, Preliminary investigations on volcanism of the Sadah region (Yemen Arab Republic), J. Volcanology, 46, 413-427, 1983.

Caristan, Y., The transition from high temperature creep to fracture in Maryland diabase, $J$. Geophys. Res., 87, 6781-6798, 1982.

Cheadle, M. J., S. McGeary, M. R. Warner, and D. H. Mathews, Extensional structures on the western U.K. continental shelf: A review of evidence from deep seismic profiling, in Continental Extensional Tectonics, Spec. Pub. 23, edited by M.P. Coward, J.F. Dewey, and P.L. Hancock, p. 445465, Geological Society of London, 1987.

Cochran, J.R., The Gulf of Aden: Structure and evolutions of a young ocean basin and continental margin, J. Geophys. Res., 86, 263-288, 1981.

Cochran, J.R., A model for development of Red Sea, Bull. Am. Assoc. Pet Geol. Bull., 67, 41-69, 1983.

Cochran, J.R., F. Martinez, M.S. Steckler, and M.A. Hobart, Conrad Deep: A new northern Red Sea deep, Origin and implications for continental rifting, Earth Planet. Sci. Lett., 78, 18-32, 1986.

Coleman, R.G., Geologic map of the Red Sea, scale 1:2,000,000, U. S. Geological Survey, 1973, in Initial Rep. Deep Sea Drill. Proj., 23, edited by R.B. Whitmarsh et al., 1974a.

Coleman, R.G., Geologic background of the Red Sea, in Initial Rep. Deep Sea Drill. Proj., 23, edited by R.B. Whitmarsh et al., 813-819, 1974b.

Coleman, R.G., The Red Sea, a small ocean basin formed by continental extension and sea floor spreading, Proc. 27th Int. Geol. Congr., 23, 93$121,1984$.

Coleman, R.G., R.J. Fleck, C.E. Hedge, and E.D. Ghent, The volcanic rocks of southwest Saudi Arabia and the opening of the Red Sea. Red Sea Research 1970-1975, Miner. Resour. Bull. Saudi Arabia Dir. Gen. Miner. Resour., 22, D1-D30, 1977.

Coleman, R.G., D.G. Hadley, R.G. Fleck, C.T. Hedge, and M.M. Donato, The Miocene Tihama 
Asir ophiolite and its bearing on the opening of the Red Sea, Evolution and Mineralization of the Arabian-Nubian Shield, I.A.G. Bull., 3, 173-186, 1979.

Coleman, R.G., R.T. Gregory, and G.F. Brown, Cenozoic volcanic rocks of Saudi Arabia, U.S. Geol. Surv. Open File Rep., OF-03-93, 82, 1983.

Colletta, B., P. Le Quellec, J. Letouzey, and I. Moretti, Longitudinal evolution of the Suez rift structure (Egypt), Tectonophysics, 153, 221-233, 1988.

Crisp, J.A., Rates of magma emplacement and volcanic output, J. Volcanol. Geotherm. Res., 20, 177-211, 1984.

Crough, S.T., Rifts and swells: Geophysical constraints on causality, Tectonophysics, 94, 23-37, 1983.

Davidson, A., and D.C. Rex, Age of volcanism and rifting in southwestern Ethiopia, Nature, 283, 657-658, 1980.

Dixon, T.H., and M.P. Golombek, Late Precambrian crustal accretion rates in northeast Africa, Geology, 16, 991-994, 1988.

Dixon, T.H., R.J. Stern, and I.M. Hussein, Control of Red Sea rift geometry by Precambrian structures, Tectonics, 6, 551-571, 1987.

Doser, D. I., The northeastward propagation of the Baikal rift: implications from earthquake source parameter studies, EOS: Trans. AGU, 69, 1311, 1988.

Dunbar, J.A., and D.S.Sawyer, How preexisting weaknesses control the style of continental breakup, J. Geophys. Res., 94, 7278-7292, 1989.

Epp, D., Possible perturbations to hotspot traces and implications for the origin and structure of the Line Islands, J. Geophys. Res., 89, 11,27311,286, 1984.

Etheridge, M. A., On the reactivation of extensional fault systems. Philos. Trans. R. Soc. London, Ser. A, 317, 179-194, 1986.

Evans, A.L., Neogene tectonic and stratigraphic events in the Gulf of Suez rift area, Egypt, Tectonophysics, 153, 235-247, 1988.

Eyal, M., Y. Eyal, Y. Bartov, and G. Steinitz, The tectonic development of the western margin of the Gulf of Elat (Aqaba) rift, Tectonophysics, 80, 3966, 1981.

Falvey, D.A., The development of continental margins in plate tectonic theory, Aust. Petrol. Explor. Assoc. J., 14, 95-106, 1974.

Fitton, J.G., The Benue Trough and Cameroon LineA migrating rift system in West Africa, Earth Planet. Sci.Lett., 51, 132-138, 1980.

Freund, R., Z. Garfunkel, and I. Zak, The shear along the Dead Sea rift, Philos. Trans. R. Soc. London, Ser. A, 267, 107-130, 1970.

Gettings, M.D., H.R. Blank, Jr., W.D. Mooney, and J.H. Healey, Crustal structure of southwest- ern Saudi Arabia, J. Geophys. Res., 91, 64916512, 1986.

Girdler, R.W., and T.R. Evans, Red Sea heat flow, Geophys. J. R. Astron. Soc., 51, 245-251, 1977.

Gordon, R.G., and D.M. Jurdy, Cenozoic global plate motions, J.Geophys. Res., 91, 1238912406, 1986.

Herzberg, C.T., W.S. Fyfe, and M.J. Carr, Density constraints on the formation of the continental Moho and crust, Contrib. Mineral. Petrol., 84, 1$5,1983$.

Hildreth, W., Gradients in silicic magma chambers: Implications for lithospheric magmatism, J. Geophys. Res., 86, 10,153-10,192, 1981.

Huang, P.Y., and S.C. Solomon, Centroid depths and mechanisms of mid-ocean ridge earthquakes in the Indian Ocean, Gulf of Aden and Red Sea, $J$. Geophys. Res., 92, 1361-1383, 1987.

Hutchinson, D. R., K. D. Klitgord, and R. S. Detrick, Block Island fault: A Paleozoic crustal boundary on the Long Island platform, Geology, 13, 875-879, 1985.

Ivins, E.R., T.H. Dixon, and M.P. Golombek, Extensional reactivation of an abandoned thrust: A bound on shallowing in the brittle regime, $J$. Struct. Geol., in press 1989.

Joffe, S., and Z. Garfunkel, Plate kinematics of the circum-Red Sea: A re-evaluation, Tectonophysics, 141, 5-22, 1987.

Kazmin, V., M.B. Seife, M. Nicoletti, and C. Petrucciani, Evolution of the northern part of the Ethiopian rift, in Geodynamic Evolution of the Afro-Arabian rift system: Rome, Italy Accademia Nazionale dei Lincei, p. 275-292, 1980.

Keen, C.E., Some important consequences of lithospheric extension, in Continental Extensional Tectonics, Spec. Pub. 23, edited by M.P. Coward, J.F. Dewey, and P.L. Hancock, p. 62-73, Geological Society of London, 1987.

Kelley, V.C., Tectonics, middle Rio Grande rift, New Mexico, in The Rio Grande Rift: Tectonics and Magmatism, edited by R. E. Reicker, p. 5770, AGU, Washington, D.C., 1979.

Kinsman, D.J.J., Rift valley basins and sedimentary history of trailing continental margins, in Petroleum and Global Tectonics, edited by A.G. Fischer and S. Judson, p. 83-128, Princeton University Press, Princeton, N.J., 1975.

Kirby, S.H., Rheology of the lithosphere, Rev. Geophys., 21, 1458-1487, 1983.

Koch, P.S., J.M. Christie, and R.P. George, Flow law of wet quartzite in the quartz field, EOS: Trans. $A G U, 61,376,1980$.

Kohn, B.P., and M. Eyal, History of uplift of the crystalline basement of Sinai and its relation to opening of the Red Sea as revealed by fission track dating of apatites, Earth Planet. Sci. Lett., 52, 129-141, 1981.

Kusznir, N.J., and R.G. Park, The extensional 
strength of the continental lithosphere: Its dependance on geothermal gradient, and crustal composition and thickness, in Continental Extensional Tectonics, Spec. Pub. 28, edited by M.P. Coward, J.F. Dewey, and P.L. Hancock, p. 35-62, Geological Society of London, 1987.

LaBreque, J. L., and N. Zitellini, Continuous sea floor spreading in Red Sea: An alternative interpretation of magnetic anomaly pattern, $A m$. Assoc. Petr. Geol. Bull., 69, 513-524, 1985.

Lachenbruch, A.H., and J.H. Sass, Heat flow in the United States and the thermal regime of the crust, in The Earth's Crust, Geophys. Monogr. Ser., vol. 20, edited by T.G. Heacock, p. 626-675, AGU, Washingotn, D.C., 1977.

Lambeck, K., Geophysical Geodesy: the slow deformations of the Earth. Clarendon Press, Oxford, 718 p., 1988.

Le Pichon, X., and J.M. Gaulier, The rotation of Arabia and the Levant fault system, Tectonophysics, 153, 271-294, 1988.

Logatchev, N.A., and N.A. Florensov, The Baikal system of rift valleys, Tectonophysics, 45, 1-13, 1978.

Lowell, J.D., G.J. Genik, T.H. Nelson, and P.M. Tucker, Petroleum and plate tectonics of the southern Red Sea, in Petroleum and Plate Tectonics, edited by A.G. Fischer and S. Judson, p. 129-153, Princeton University Press, Princeton, N. J., 1975.

Lynch, H.D., and P. Morgan, The tensile strength of the lithosphere and the localization of extension, in Continental Extensional Tectonics, Spec. Pub. 28, edited by M.P. Coward, J.F. Dewey, and P.L. Hancock, p. 53-65, Geological Society of London, 1987.

Makris, J., B.A. Allam, and L. Moller, Deep seismic studies in Egypt and their interpretation, EOS: Trans. $A G U, 62,230,1981$.

Maurin, J. C., J. Benkhelil, and B. Robineau, Fault rocks of the Kaltungo lineament, NE Nigeria, and their relationship with Benue Trough tectonics, $J$. Geol. Soc. London, 143, 587-599, 1986.

McConnell, R.B., Geological development of the rift system of East Africa, Geol. Soc. Am. Bull., 83, 2549-2572, 1972.

McGarr, A., and N.C. Gay, State of stress in the earth's crust, Ann. Rev. Earth Planet. Sci., 6, 405-436, 1978.

McKenzie, D.P., A possible mechanism for epirogenic uplift, Nature, 307, 616-618, 1984.

McKenzie, D.P., D. Davis, and P. Molnar, Plate tectonics of the Red Sea and East Africa, Nature, 226, 243-248, 1970.

Miller, P.M., and H. Barakat, Geology of the Safaga concession, northern Red Sea, Egypt, Tectonophysics, 153, 123-136, 1988.

Miller, S.P., K.C. MacDonald, and P.F. Lonsdale, Near bottom magnetic profile across the Red Sea, Mar. Geophys. Res., 7, 401-418, 1985.
Mohr, P., Perspectives on the Ethiopian volcanic province, $J$. Volcanol., 46, 23-43, 1983.

Mooney, W.D., M.E. Gettings, H.R. Blank, and

profile: a traveltime interpretation of crustal and upper mantle structure, Tectonophysics, 111, 173-246, 1985.

Morgan, P., and I.B. Ramberg, Physical changes in the lithosphere associated with thermal relaxation after rifting, Tectonophysics, 143, 1-11, 1987.

Morgan, P., F.K. Boulos, S.F. Hennin, A.A. El Sherif, A.A. El Sayed, N.Z. Basta, and Y.S. Melek, Heat flow in eastern Egypt: The thermal signature of a continental breakup, J. Geodyn., 4, 107-131, 1985.

Morgan, P., W.R. Seager, and M.P. Golombek, Cenozoic thermal, mechanical and tectonic evolution of the Rio Grande rift, J. Geophys. Res., 91, 6263-6276, 1986.

Morgan, W.J., Plate motions and deep mantle convection, Mem. Geol. Soc. Am., 132, 7-22, 1972.

Morrow, C.A., L.Q. Shi, and J.D. Byerlee, Strain hardening and strength of clay-rich fault gouges, J. Geophys. Res., 87, 6771-6780, 1982.

Murrell, S.A.P., and I.A.H. Ismail, The effect of decomposition of hydrous minerals on the mechanical properties of rocks at high pressure and temperatures, Tectonophysics, 31, 207-258, 1976.

Omar, G.I., B.P. Kohn, T.M. Lutz, and H. Faul, The cooling history of Silurian to Cretaceous alkaline ring complexes, South Eastern Desert, Egypt, as revealed by fission-track analysis, Earth Planet. Sci. Lett., 83, 94-108, 1987.

Overstreet, W.C., D.B. Stoeser, E.F. Overstreet, and G. H. Goudarzi, Tertiary laterite of the As Sarat Mountains, Asi Province, Kingdom of Saudi Arabia, Miner. Resour. Bull. Saudi Arabia Dir. Gen. Miner. Resour., 21, 30 p., 1977.

Pallister, J.S., Magmatic history of Red Sea rifting: Perspective from the central Saudi Arabian coastal plain, Geol. Soc. Am. Bull. 98, 400-417, 1987.

Pallister, J.S., J.S. Stacey, L.B. Fischer, and W.R. Premo, Arabian shield ophiolites and late Proterozoic microplate accretion, Geology, 15, 320-323, 1987.

Phillips, J.D., and D.A. Ross, Continuous seismic reflection profiles in the Red Sea, Philos. Trans. $R$. Soc. London, Ser. A, 267, 143-152, 1970.

Purser, B.H., and H. Hotzl, The sedimentary evolution of the Red Sea rift: a comparison of the northwest (Egyptian) and northeast (Saudi Arabian) margins, Tectonophysics, 153, 193-208, 1988.

Qureshi, I.R., Gravity measurements in the Northeastern Sudan and crustal structure of the Red Sea, Geophys. J. R. Astron. Soc., 24, 119-135, 1971.

Raleigh, C.B., and M.S. Paterson, Experimental deformation of serpentinite and its tectonic implications, J. Geophys. Res., 70, 3965-3985, 1965. 
Ramberg, I.B., and P. Morgan, Physical characteristics and evolutionary trends of continental rifts, Proc. 27th Int. Geol. Congress, Moscow, Tectonics, 27, 165-216, 1984.

Ratcliffe, N. M., W. C. Burton, R. M. D'Angelo, and J. K. Kostain, Low angle extensional faulting, reactivated mylonites, and seismic reflection geometry of the Newark basin margin in eastern Pennsylvania, Geology, 14, 766-770, 1986.

Reches, Z., and G. Schubert, Models of postMiocene deformation of the Arabian plate, Tectonics, 6, 707-725, 1987.

Ries, A.C., R.M. Shackleton, R.H. Graham, and W.R. Fitches, Pan African structures, ophiolites and melange in the Eastern Desert of Egypt: a traverse at $26^{\circ} \mathrm{N}, J$. Geol. Soc. London, 140, 75-95, 1983.

Roeser, H.A., A detailed magnetic survey of the southern Red Sea, Geol. Jahrb., D-13, 131-153, 1975.

Schmidt, D.L., and D.G. Hadley, Stratigraphy of the Miocene Baid formation, southern Red Sea coastal plain Kingdom of Saudi Arabia, U.S. Geol. Surv. Open File Rep., 85-241, 1985.

Schmidt, D.L., D.G. Hadley, and G.F. Brown, Middle Tertiary continental rift and evolution of the Red Sea in southwestern Saudi Arabia, U.S. Geol. Surv. Open File Rep., OF-03-6, 1982.

Sebai, A., G. Feraud, G. Giannerim, R. Campredon, and $\mathrm{H}$. Bertrand, ${ }^{39} \mathrm{Ar}-{ }^{40} \mathrm{Ar}$ dating on Cenozoic mafic volcanics of the Arabian plate associated with early Red Sea opening, Terra Cognita, 7, 201, 1987.

Seigel, H.O., A theory of fracture of materials and its application to geology, EOS: Trans. $A G U, 31$, 611-619, 1950.

Sengor, A.M.C., and K. Burke, Relative timing of rifting and volcanism on earth and its tectonic implications, Geophys. Res. Lett., 5, 419-421, 1978.

Shudofsky, G. N., S. Cloetingh, S. Stein, and R. Wortel, Unusually deep earthquakes in East Africa: Constraints on the thermo-mechanical structure of a continental rift system, Geophys. Res. Lett., 14, 741-744, 1987.

Sibson, R.H., Continental fault structure and the shallow earthquake source, J. Geol. Soc. London, 140, 741-767, 1983.

Solomon, S.C., R.M. Richardson, and E.A. Bergman, Tectonic stress: Models and magnitudes, J. Geophys. Res., 85, 6086-6095, 1980.

Solomon, S.C., and H.H. Sleep, Some simple physical models for absolute plate motion, J. Geophys. Res., 79, 2557-2567, 1974.

Spohn, T., and G. Schubert, Convective thinning of the lithosphere: A mechanism for rifting and midplate volcanism on Earth, Venus and Mars, Tectonophysics, 94, 67-90, 1983.

Stacey, J.S., and R.A. Agar, U-Pb isotopic evidence for the accretion of a continental microplate in the
Zalam Region of the Saudi Arabian Shield, $J$. Geol. Soc. London, 142, 1189-1203, 1985.

Steckler, M.S., F. Berthelot, N. Liberis, and X. LePichon, Subsidence in the Gulf of Suez: Implications for rifting and plate kinematics, Tectonophysics, 153, 249-270, 1988.

Stein, S., H.J. Melosh, and J.B. Minster, Ridge migration and asymmetric sea floor spreading, Earth Planet. Sci. Lett., 36, 51-62, 1977.

Steinitz, G., Y. Bartov, and J.C. Hunzicker, K-Ar age determinations of some Miocene-Pliocene basalts in Israel: Their significance to the tectonics of the rift valley, Geol. Mag., 115, 329-340, 1978.

Steinitz, G., Y. Bartov, M. Eyal, and Y. Eyal, K-Ar age determination of Tertiary magmatism along the western margin of the Gulf of Elat, Geol. Surv. Israel Current Res. 1980, 27-29, 1980.

Stern, R.J., The Najd fault system, Saudi Arabia and Egypt: a Late Precambrian rift-related transform system?, Tectonics, 4, 497-511, 1985.

Sykes, L.R., Intraplate seismicity, reactivation of pre-existing zones of weakness, alkaline magmatism, and other tectonism postdating continental fragmentation, Rev. Geophys., 16, 621-688, 1978.

Tabor, R. W., R. K. Mark, and R. H. Wilson, Reproducibility of the K-Ar ages of rocks and minerals: An empirical approach, U.S. Geol. Surv. Bull., 1654, 5 p., 1985.

Turcotte, D.L., Mechanisms of crustal deformation, J. Geol. Soc. London, 140, 701-724, 1983.

Tweto, O., The Rio Grande rift system in Colorado, in The Rio Grande Rift: Tectonics and Magmatism, edited by R.E. Reicker, p. 33-56, AGU, Washington, D.C., 1979.

U.S. Defense Mapping Agency, Operational Navigation Charts, scale 1:1,000,000, Washington, D.C., 1981 .

Vail, J. R., Pan-African (Late Precambrian) tectonic terrains and the reconstruction of the Arabian-Nubian shield, Geology, 13, 839-842, 1985.

Vink, G.E., A hotspot model for Iceland and the Voring Plateau, J. Geophys. Res., 89, 9949 9959, 1984.

Voggenreiter, W., H. Hotzl, and A.R. Jado, Red Sea related history of extension and magmatism in the Jizan area (Southwest Saudi Arabia): Indication for simple shear during early Red Sea rifting, Geol. Rundsch., 77, 257-274, 1988.

Weeks, J.D., L.A. Reinen, T.E. Tullis, and M.L. Blanpied, Friction constitutive behavior of serpentinite, EOS: Trans. AGU, 69, 1463, 1988.

Weinstein, S. A., and P. L. Olson, The proximity of hotspots to convergent and divergent plate boundaries, Geophys. Res. Lett., 16, 433-436, 1989.

Wernicke, B., Uniform-sense normal simple shear of the continental lithosphere, Can.J. Earth Sci., 22, 108-125, 1985.

Wilson, J. T., Did the Atlantic close and then re- 
open? Nature, 211, 676-681, 1966.

Wilson, J.T., Aspects of the different mechanics of ocean floors and continents, Tectonophysics, 8 , 281-284, 1969.

Wood, C.A., Continental rift jumps, Tectonophysics, 94, 529-540, 1983.

Zamarayev, S.M., and V.V. Ruzhich, On the relationships between the Baikal rift and ancient structures, Tectonophysics, 45, 41-47, 1978.

Zanettin B., E. Justin-Visentin, M. Nicoletti, and E.M. Piccirillo, Correlations amount Ethiopian volcanic formations with special references to the chronological and stratigraphical problems of the Trap series, in Geodynamic Evolution of the AfroArabian rift system: Rome, Italy Accademia Nazionale dei Lincei, p. 231-245, 1980.
Zoback, M.L., and M.D. Zoback, Faulting patterns in north-central Nevada and strength of the crust, J. Geophys. Res. 85, 275-284, 1980.

T. H. Dixon, E. R. Ivins, and B. J. Franklin, Division of Earth and Planetary Sciences, Jet Propulsion Laboratory, Mail Stop 183-501, 4800 Oak Grove Drive, Pasadena, CA 91109

(Received May 10, 1988; revised May 4, 1989;

accepted May 5, 1989.) 